\title{
THE VEGETATION AND FLORA OF THREE HUMMOCK ISLAND, WESTERN BASS STRAIT
}

\author{
by Stephen Harris and Jayne Balmer
}

(with one table, four text-figures, nine plates and an appendix)

\begin{abstract}
Harris, S. \& Balmer, J., 1997 (31:viii): The vegetation and flora of Three Hummock Island, western Bass Strait. Pap. Proc. R. Soc. Tasm. 131: 37-56. https://doi.org/10.26749/rstpp.131.37 ISSN 0800-4703. Parks and Wildlife Service, Department of Environment and Land Management, GPO Box 44A, Hobart, Tasmania, Australia 700I.
\end{abstract}

A survey of the vegetation of Three Hummock Island Nature Reserve recorded 289 vascular higher plant species, 60 of which were introduced. Of the native flora, six are classified as rare or vulnerable. Clarke Island, at a similar latitude in Eastern Bass Strait, has a significantly richer flora, including an element of Mainland Australian/Bassian flora for which the island is the southernmost limit. In contrast, there are no species known from Three Hummock Island that do not occur on mainland Tasmania. The greater length of time during which the land bridge at the eastern end of Bass Strait was exposed is, therefore, reflected in the flora. Three Hummock Island was cut off for a much longer period with no land connections to the north, therefore has a more insular Tasmanian flora. Climatic differences may have exacerbated the contrast.

Nine vegetation mapping communities are defined, the largest proportion of the island being covered by Myrtaceae-dominated scrub. The main changes in the vegetation since the time of European discovery have been the clearing of much of the relatively fertile calcareous sands for grazing and the consequent loss of most of the Eucalyptus viminalis forests, an increased fire frequency and the introduction of exotic plants. Fire and weeds are the major vegetation management issues on the island.

Key Words: Flora, vegetation, Bass Strait, Tasmania, biogeography, Three Hummock Island, Nature Reserve, Clarke Island, coastal vegetation

\section{INTRODUCTION}

Three Hummock Island comprises 7284 ha and is one of the three larger islands in the Hunter Group off northwestern Tasmania (fig. 1). Despite this, there is a surprising dearth of published information about the vegetation. What little there is, either is very general and results from broad extrapolation with little or no fieldwork on the island, or treats specific aspects of the flora within a more general state context.

Some vegetation types have been examined in broader systematic studies. Kirkpatrick (1977) sampled the heathland vegetation and Kirkpatrick \& Harris (1995) reported the results of an analysis of coastal plant communities which included samples from Three Hummock Island. Kirkpatrick \& Harwood (1981, 1983a, b) sampled four lagoons on the island in their statewide wetland survey. Oblique or casual references to the vegetation or flora of the island have been made by Atkinson (1890), Alliston (1966) and some early navigators, including Baudin (Cornell 1974) and Bass (Collins 1802). The island vegetation has been mapped at 1:500 000 from air photo interpretation (Kirkpatrick \& Dickinson 1984), and land systems, i.e. soil/geomorphic/vegetation units, were mapped by Richley (1984). The island is known to have been prospected for orchids, and parties of natural history enthusiasts have visited the island from time to time.

The island has been Crown land, held under lease since at least before 1850 but resumed by the Crown in 1976, and subsequently proclaimed a Nature Reserve under the National Parks and Wildlife Act 1970 by virtue of Statutory Rule No. 303 of 1977. Fire management has since become one of the most important issues for the Parks and Wildlife Service. Fire management planning requires information about the vegetation. This was one of the primary motives for the present study. The inventory of species and plant communities in a Nature Reserve also assists nature conservation planning in a state context. Biological surveys of islands have been recommended as a national priority (McNamara 1989).

The aims of this study were to prepare a detailed vegetation map, describe the plant communities on the island and the major factors influencing vegetation pattern, and record the higher plants observed on the island.

\section{METHODS}

Two weeks were spent on the island between 2 and 14 October 1995. During this time the island was traversed on foot, in order to sample the full range of vegetation types likely to be found on the island as well as all likely plant species habitats. Fifty-nine $100 \mathrm{~m}^{2}$ plots were located subjectively, without preconceived bias (Mueller-Dombois \& Ellenberg 1974) in the range of vegetation types, and used for descriptions of structure, species composition and, if possible, age since last fire. A species list was compiled on transects through similar vegetation types and locations of plot and point-based observations were marked directly on an aerial photograph enlargement. Specimens of most higher plant species observed were collected and the material was subsequently lodged in the Tasmanian Herbarium.

Apparent vegetation types were delineated on 1993 , 1:50 000 black and white aerial photographs and checked in the field. Structural nomenclature follows Specht (1970) and plant nomenclature follows Buchanan (1995). Grid references given in the text are standard AMG grid references from the Tasmap 1:100 000 map sheet 7816 Hunter.

Human disturbances can have a major impact on island species equilibrium (Whittaker 1995). Historical sources were examined to help determine vegetation change on Three Hummock Island. 


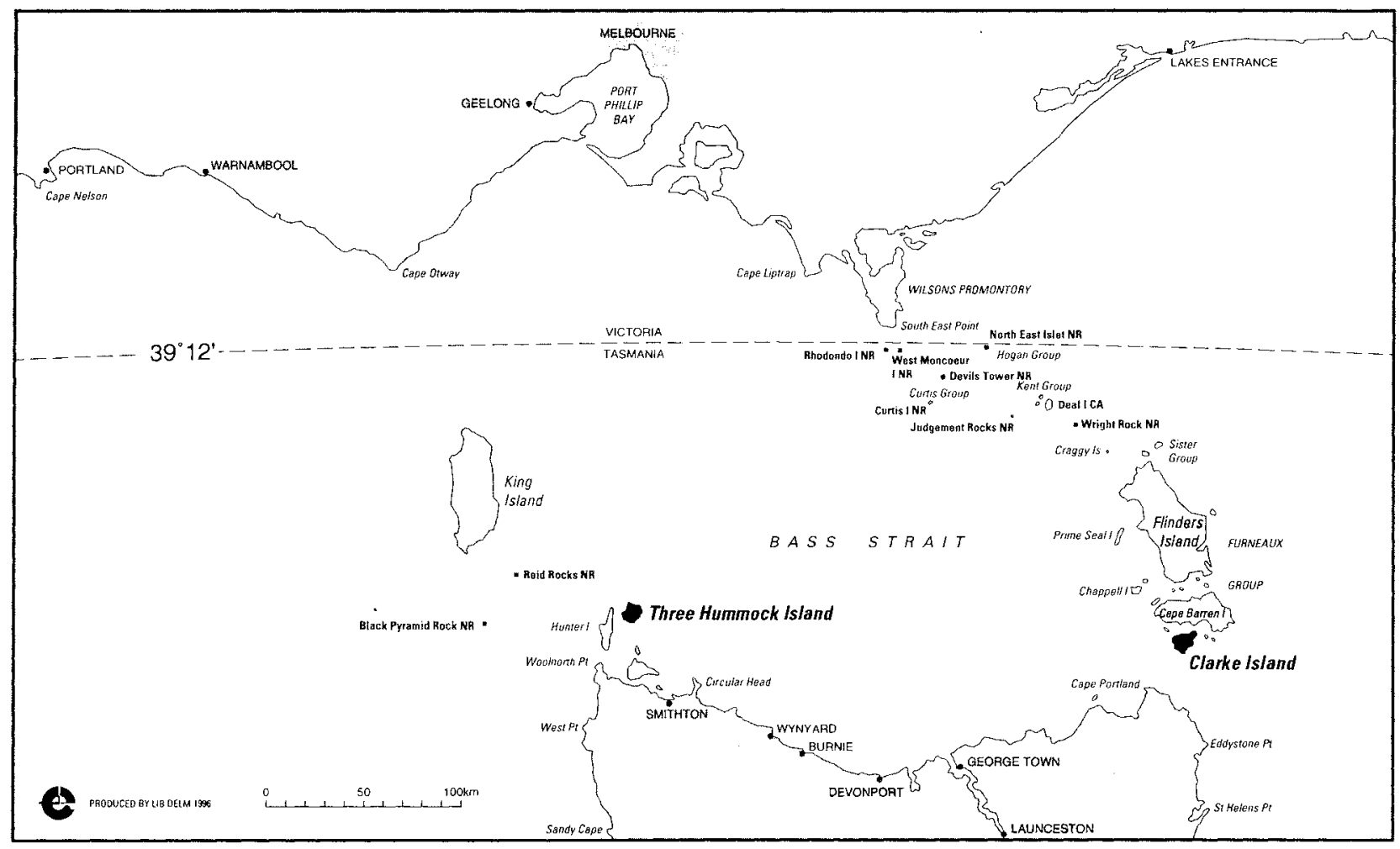

FIG. I - Location of the study area and Clarke Island.

\section{A BRIEF HISTORY OF THE ISLAND.}

There are very few early historical references to the islands in the Hunter Group. The islands were not known to Europeans at all until Bass' voyage from the east in 1798 through the strait bearing his name. Three Hummock Island was named by Flinders who anchored on the north coast of the island in 1798. The wreck of the Sydney Cove (1797) in the Furneaux Group led almost directly to the discovery of the Strait, which soon after becarne the route for shipping from Europe rather than around the "Cape of Van Diemen". Interest in western Bass Strait by the early navigators around the turn of the 18 th century was probably due in part to the new strategic importance to shipping of the western approaches to the Strait.

The earliest reference, albeit indirect, to the vegetation of Three Hummock Island was given by Bass in his journal of his exploratory voyage of 1798 and reported in Collins (1802):

"There was reason to believe, that the sea here had a communication through into the unexplored bight to the eastward of Three Hummock Island; in which case the pointed part of the main, whose vegetation bore so great a resemblance to that of Three Hum mock Island, would also be an island."

Earlier, Collins further gave the description from Bass of the vegetation of Hunter Island: "... pointed part of the main, which in height and starved vegetation very much resembled Three Hummock Island."

Bowdler (1980) cited an account by Flinders of Bass's landfall on Three Hummock Island where Flinders stated that Bass "....found it impenetrable from the closeness of the tall brush wood, although it had been partially burnt not long before".
Only a few years later, Freycinet (reproduced in Plomley 1983) of the 1802 Baudin expedition described his landing on Three Hummock Island:

"We landed only once, towards the western end of Coulomb Bay. Our landing was accomplished easily in a little sandy cove, well sheltered and very snug, whose heads were low and composed of a grey micaceous granite. This part of the island is wooded yet lacking tall trees. A little distance from the shore the terrain is extremely sandy, but on moving further into the interior one finds land of quite good quality covered with several different kinds of plants. We perambulated the woods in different directions. They are so tangled and so obstructed with trees blown down by the winds that we had difficulty getting out of them. We often saw large masses of granite sticking out of the ground."

It appears then that the island had dense scrubby vegetation. If the island had been free of fire for millennia, then tall forests with much more open understorey would be expected. Pre-European sources of fire would have been lightning and Aboriginal visitors. Plomley stated (1983: 193) that there was evidence of Aboriginal use of the island and suggested that Baudin's expedition might have noted the Aboriginal smokes because "... one of the reference points was designated pointe de la fumée ('smoky point' = Point Cassard)".

Subsequent references to the island in the 19 th century are sparse. It seems that the island had settlers prior to 1852. The Italian revolutionary, Garibaldi, who visited the island in 1852, stated (Garibaldi 1889, quoted in AOT corres. file):

"1852. In the Indian Ocean, outside the Straits of Lombok, we found the breezes constant from the east, 
at a few degrees distance. Keeping the ship's head to the wind, we continued as far as about $40^{\circ} \mathrm{S}$., when, finding the wind westerly, we passed through Bass's Strait, between Australia and Van Diemen's Land. Touching at one of the Hunter Islands, to take in water, we found a small farm, lately deserted by an Englishman and his wife, on the death of his partner. This information was obtained from a board erected on the settler's grave, which set forth in brief the history of the little colony. 'The husband and wife', said the inscription, 'unable to bear the lonliness [sic] of the desert island, left it, and returned to Van Diemen.'

"The most important part of the settlement was a little one-storied dwelling-house, rough, but comfortable, carefully built, and furnished with tables, beds, and chairs - not luxurious, indeed, but all bearing the impress of that comfort which seems so natural to the English. We also found a garden - a most useful discovery, as it enabled us to take on board an abundant supply of fresh potatoes and other vegetables.

"How often has that lonely island in Bass's Strait deliciously excited my imagination, when, sick of this civilized society so well supplied with priests and police agents, I returned in thought to that pleasant bay, where my first landing startled a fine covey of partridges, and where, amid lofty trees of a century's growth, murmered [sic] the clearest, the most poetical of brooks, where we quenched our thirst with delight, and found an abundant supply of water for the voyage."

It is likely that Garibaldi anchored at Chimney Corner (R. Alliston, pers. comm.). There is no tall forest near this vicinity today.

Atkinson (1890) reported on a visit to the island in November that year. By this time the island was being leased from the government by Captain John Burgess. Burgess had cleared some areas of the island. Atkinson described his attempts to attain the summit of South Hummock, which, at the first instance, was prevented by the dense scrub. The second successful attempt was also a struggle, "walking, cutting and crawling through one of the densest scrubs I ever experienced ..." Interestingly, the only plants Atkinson mentions are ones collected near the summit and with which he is not familiar, but which occur widely over the island. These were determined for him by Baron von Muefler and are Styphelia lanceolata (most likely Leucopogon australis), Pimelea ligustrina (could this have been $P$. linifolia, which is common?), Phyllanthus gunnii and Boronia polygalifolia $(=B$. anemonifolia). Atkinson remarks that these are "all rather rare". Except for $P$. gunnii, which is sparsely distributed, these determinations probably represent species which are now extremely common on the island.

Since at least the mid 1800 s, the island has been a farm, and some of the sandy areas were eventually cleared for stock grazing. Many of these areas are now reverring to scrub, but for many years there was regular burning of sandy areas each spring to keep back the scrub and encourage the grasses. Sowing of exotic grass species was carried out, with regular top-dressing with superphosphate and trace elements ( $\mathrm{Co}, \mathrm{Cu})$ on the more acid soils (J. Alliston pers. comm.). Some cultivation occurred on the better home paddocks, and the only known patch of basaltic soil on the island, behind East Telegraph Beach, was cleared, ploughed and sown to potatoes (Alliston 1966).
Since the lease on the island was resumed by the Government in 1976, the former lessees retain a life tenancy of the homestead at Chimney Corner. The island is now managed as a Nature Reserve. So far, this has involved maintaining a flock of sheep on the home paddocks, which helps to preserve an effective fire break for the buildings at Chimney Corner and keep the home airstrip open. Some firing has been carried out, with the aim of protecting built assets. Marram grass (Ammophila arenaria) planting was carried out by the Parks and Wildlife Service on the large sand blowout behind West Telegraph Beach in 1986, but trial planting of Marram grass was carried out on the island in the 1940s. Commercial activity carried out on the island is seasonal muttonbirding in March and April. The island is also used as an interchange by abalone poachers, who fly out illegally harvested shellfish from the Telecom airstrip in the centre of the island. The airstrip was constructed in 1973 for servicing a now-defunct telecommunications tower on South Hummock. An area of $58.2 \mathrm{~m}^{2}$ near Cape Rochon is owned by the Commonwealth Government for lighthouse purposes.

\section{PHYSICAL DESCRIPTION AND CLIMATE}

\section{Location and Climate}

Three Hummock Island is situated $30 \mathrm{~km}$ north of the northwest corner of the Tasmanian mainland and $4 \mathrm{~km}$ east of the northern end of Hunter Island. It is at latitude $40^{\circ} 25^{\prime}$ longitude $144^{\circ} 55^{\prime}$ and so experiences the full impact of the "Roaring Forties" with the consequent strong westerly prevailing wind. The average rainfall is $939 \mathrm{~mm}$ per annum. The minimum recorded annual rainfall is $651 \mathrm{~mm}$ and the maximum recorded annual rainfall is $1233 \mathrm{~mm}$ (Bureau of Meteorology 1996). Rain falls throughout the year, with a maximum of $228 \mathrm{~mm}$ in July and a minimum of $10 \mathrm{~mm}$ in February (Bureau of Meteorology 1996). The temperature is mild throughout the year, with a daily average minimum of about $13^{\circ} \mathrm{C}$ and a daily average maximum of about $20^{\circ} \mathrm{C}$ for February. The daily average minimum in July is $8^{\circ} \mathrm{C}$ and the daily average maximum in the same month is $12.9^{\circ} \mathrm{C}$ (Bureau of Meteorology 1996).

\section{Geology and Soils}

Three Hummock Island is compact in shape and has about $50 \mathrm{~km}$ of coastline, of which about $40 \mathrm{~km}$ consist of exposed granite outcrops, while $10 \mathrm{~km}$ consist of sandy beaches and dunes.

The geology of Three Hummock Island has been described by Jennings (1976) as "simple, consisting of a single granite pluton, with only small rare inclusions of original host sediments". The granite (Lower Carboniferous-Devonian) is not otherwise known from the northwestern island region of Tasmania. Elsewhere in this region (but absent from Three Hummock), Precambrian sediments predominate (Richley 1984, Jennings \& Cox 1978). There is a small area of basalt $\left(0.3 \mathrm{~km}^{2}\right)$ about $1 \mathrm{~km}$ from East Telegraph beach.

Three contrasting soils are recorded for the island. The soil which overlies the basalt is a brown sandy loam (Jennings 1976). Overlying the granite bedrock across most of the island is a veneer of Quaternary sands, which gives rise to 
dark acid sandy soils with a $\mathrm{pH}$ of about 4 (Lees 1976, Jennings 1976, Richley 1984). Quaternary coastal calcareous sand deposits form extensive dune systems, which have been recently stabilised on the west and southwest of the island (Richley 1984). These sands have a $\mathrm{pH}$ of between 8 and 9 (Lees 1976).

\section{Topography}

Low hills exist in a band around the east of the island from the northeast to the southwest (fig. 2). The three highest hills, from which the island is named, are North Hummock $160 \mathrm{~m}$ a.s.l., Middle Hummock $100 \mathrm{~m}$ a.s.l. and South Hummock $237 \mathrm{~m}$ a.s.l. The hills border a broad, flat plain in the centre of the island. The drainage from this plain is blocked by the extensive dune systems to the west, resulting in the development of swamps and lagoons (pl. 1).

\section{VEGETATION COMMUNITIES}

\section{Scrub on Acid Sands}

This formation covers 3976 ha or $54 \%$ of the island and is the most common and widespread vegetation type. The typical height of this scrub is between 4 and $5 \mathrm{~m}$ and it comprises a dense thicket, usually dominated by Leptospermum scoparium, Melaleuca ericifolia and Banksia marginata, but also including $M$. squarrosa, Acacia mucronata, A. verticillata and Leucopogon australis. Eucalyptus nitida is often emergent (pl. 2). Other species sometimes occurring in the lower to mid layers are Pimelea linifolia, Epacris impressa, L. ericoides and Dillwynia glaberrima. Dieback of Pteridium esculentum is usually very evident at this stage of succession.

This 4-5 m high scrub results mainly from a widespread fire about 1960. Low, closed scrub/shrubland, which regenerated from the widespread fre of 1982 , is evident everywhere with varying heights, depending on site

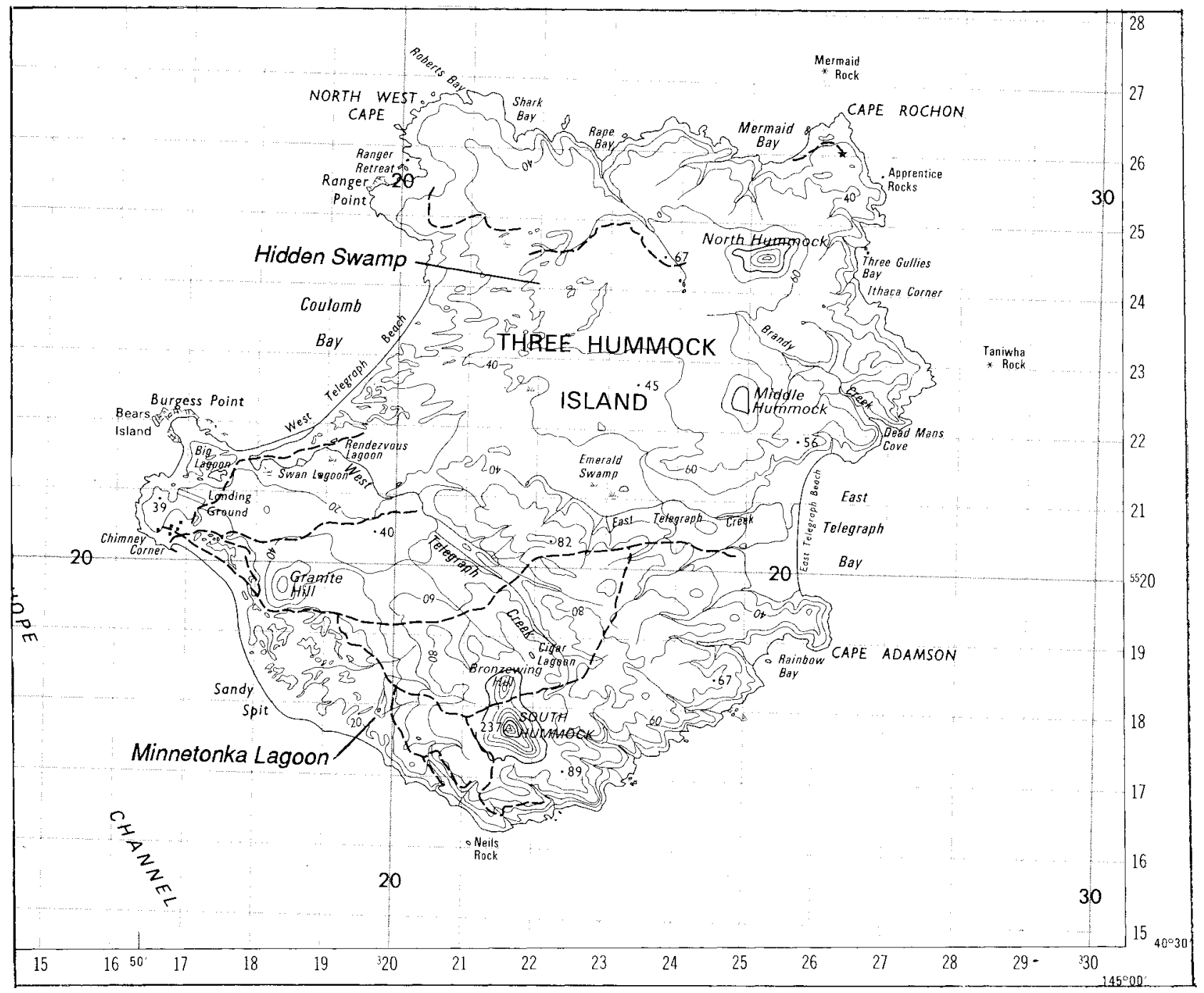

FIG. 2 - Topography and locations mentioned in the text. The grid lines are $1 \mathrm{~km}$ apart. 


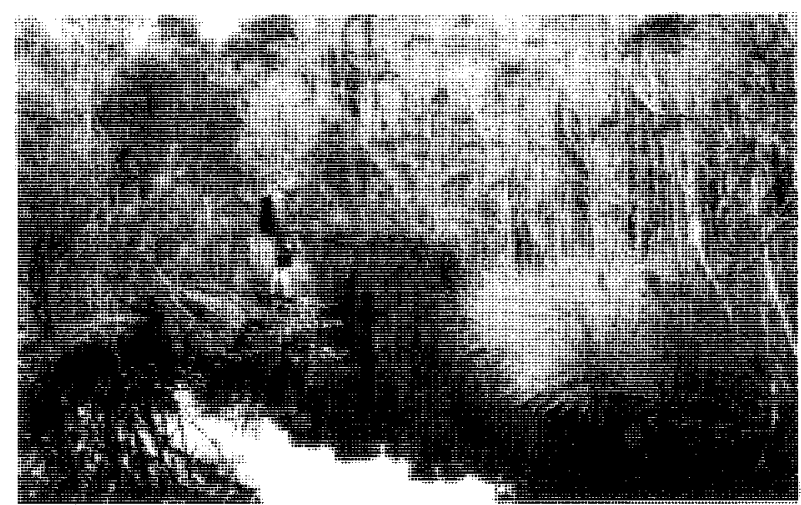

PLATE 1

The eastern plateau surface declines in altitude to the west. $A$ zone of wetlands occurs where drainage to the west is blocked by sandsheets on the coast. The wetlands are dominated by Melaleuca ericifolia.

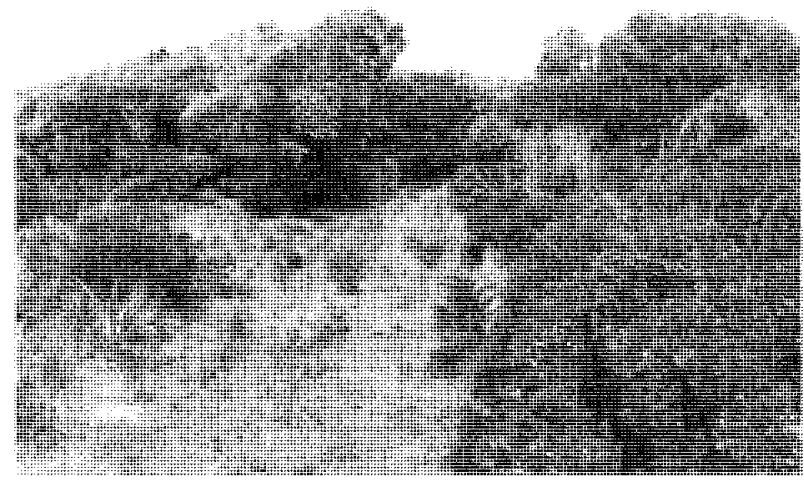

PLATE 2

Eucalyptus nitida scrub near the Mermaid rookery hut. There is a gradation from grassy heath (with Boronia anemonifolia, bracken, and Poa poiformis in the foreground) to dense scrub, where Leptospermum scoparium and Acacia verticillata are codominant with the eucalypt.

conditions but mainly between 2 and $3 \mathrm{~m}$. The species diversity in the younger formation is only slightly higher. For example, in addition to the species mentioned above, there may also be Aotus ericoides, Cassytha pubescens, Melaleuca squamea and Restio complanatus. Comparing paired plots in similar vegetation resulting from the two fire ages, it is evident that an accumulation of brown fibrous peat (Ao horizon) up to $50 \mathrm{~mm}$ depth over the dark-grey mineral soil in the older $(35$ y.o.) formation is reduced to less than $10 \mathrm{~mm}, 13$ years after the subsequent fire.

Most species in the scrub are present in the sedgeland/ heath at least at trace levels. It is, therefore, apparent that all the heaths on the island on acid sands have the potential to develop into scrubs with the above species composition.

Burning the scrub vegetation results in different rates of pose-fire growth, which apparently vary on the basis of soil drainage. The growth rates in the better drained sandy soils are rapid, and the vegetation returns to scrub in about ten years. Frequent firing is required to maintain species such as Hibbertia procumbens, Epacris lanuginosa, Sprengelia incarnata, Acacia suaveolens and Leucopogon collinus for any length of time in the vegetation on these better drained

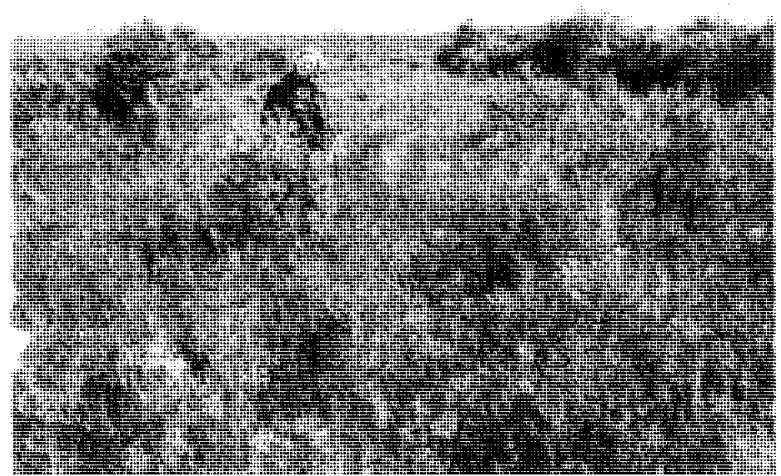

PLATE 3

A swathe of heath about ten years old on acid sands. South Hummock is visible in the left distance.

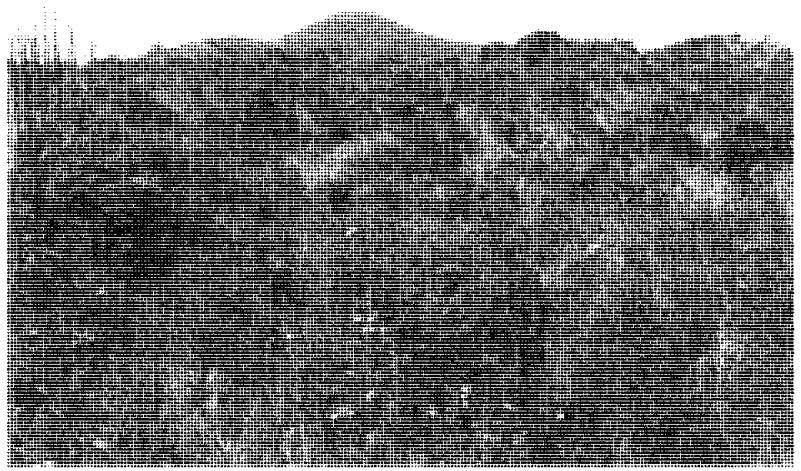

PLATE 4

On the eastern plateau surface of the island, soils are peaty, siliceous and acid and support heath and shrubland. North Hummock is in the background.

sites. These sites do not support the more characteristic western Tasmanian sedgeland species, such as Empodisma sp., Lepidosperma spp. or Lepyrodia sp. The lack of recent burning in the drier parts of the island has resulted in the restriction of the drier heaths to relarively small areas, in comparison to the scrub and wet sedgeland heaths, which are maintained for longer periods in the absence of fire.

\section{Sedgeland/Heath}

This formation occupies 81 ha or about $1 \%$ of the island, and comprises a subset of the scrub flora Banksia marginata. Leptospermum scoparium, Melaleuca squarrosa, $M$. squamea, Leucopogon australis, Gahnia grandis and Epacris impressa (pls 3, 4). Additionally, it includes typical sedgeland hearh species, of which Sprengelia incarnata, Dillwynia glaberrima, Empodisma minus, Patersonia fragilis, Restio complanatus, Hibbertia procumbens, Lepyrodia tasmanica, Bauera rubioides, Epacris lanuginosa, Selaginella uliginosa and Cassytha glabella are the most widespread and characteristic. A number of species are locally common but geographically restricted in this flora, for example E. obtusifolia, Lepidosperma filiforme, 
Schoenus lepidosperma and $H$. prostrata. This may be caused by environmental patchiness or intolerance to the range of past fire regimes experienced in many parts of the island. Others are faithful but only occasional: Comesperma retusum, Xyris muelleri, Drosera peltata and Xanthosia dissecta.

In the most poorly drained areas of the island with the exception of areas permanently flooded, acid peat soils have developed.

There are relarively few obligate seeders, and recovery after fire is rapidly achieved, mainly by resprouting. Growth rates are stunted in this environment but, where fire is excluded for long enough, the community succeeds to scrub, as described elsewhere in this study. The greatest species diversity is in heaths recently burnt, when species intolerant of shading are temporarily abundant; for example D. pygmaea and Boronia parvifolia. Xanthosia dissecta and $H$. prostrata were only found in the most recently burnt areas.

\section{Scrub on Calcareous Sands}

This formation is restricted to wind-blown sands of marine origin, mainly occurring behind West Telegraph Beach and along the south coast. It comprises 428 ha, which is $6 \%$ of the island, but would have been more extensive in the past, since much of the native vegetation has been cleared for grazing sheep and cattle (pl. 5).

There is a distinctive set of species which characterise these alkaline sands. The dominant species of the scrub are Leptospermum laevigatum, Banksia marginata and Leucopogon australis. Leptospermum laevigatum is replaced by $L$. scoparium and $L$. glaucescens on the acid sands. A group of species with a high fidelity to calcareous sands includes Myoporum insulare, Acacia sophorae and Olearia glutinosa. These species may represent the components of a climax scrub-low closed forest vegetation.

The ridges have more depauperate understoreys, while swales are more apparently species-rich, possibly because of more reliable moisture availability together with leaching of nutrients from the dune profile. Apart from a whole suite of pasture and exotic species, which have invaded from the old pasture, other characteristic understorey species, though not totally faithful to the scrub on alkaline dune sands, include: Senecio odoratus, Urtica incisa, Apalochlamys spectabilis, Olearia ramulosa, Actites megalocarpa and Carpobrotus rossii. In swale areas, a grassy bottom of Poa poiformis with intertussock herbs often occurs, while the ground layer on the ridges is mainly compact leaf litter from the usually dense $L$. laevigatum scrub. Pendant mats of Rhagodia candolleana and Tetragonia implexicoma are prevalent in scrub which has not been burnt for some time. Herbs such as Galium australe, Daucus glochidiatus, Apium prostratum, Dichondra repens and Hydrocotyle muscosa are common in the ground layer.

Some areas of alkaline sands have been used as rookeries.

\section{Wetlands}

Wetlands comprise 58 ha or $<1 \%$ of the island. The main belt of wetlands occurs north to south on the landward side of the marine sands of the west coast, which block westward drainage. Emerald Lagoon is a major wetland, which collects drainage in the headwaters of East Telegraph Creek. Minor estuarine wetlands occur at the mouth of East Telegraph Creek and West Telegraph Creek.

The wetlands on the acid sands are freshwater but those nearer the west coast are more saline. The permanent lagoons within the calcareous sands have a higher diversity of wetland flora than either those on the acid sands or those that are ephemeral. For example, Big Lagoon was observed to have more than 20 species, including Triglochin procera, Lemna disperma, Myriophyllum salsugineum in the deepwater zone; then Villarsia reniformis (with Myriophyllum) and Ranunculus amphitrichus and Eleocharis acuta in the shallow zone within the boundary of the most reliable water level; then a fringing zone of mainly Ranunculus, Isolepis subtillissima, Erythranthera sp., Eryngium vesiculosum, Cotula coronopifolia, Pratia surrepens and Limosella lineata; then an outer zone of Melaleuca ericifolia scrub over a sparse ground cover of Carex appressa. Juncus kraussii is on the wind-exposed edge of the lagoon shore.

The M. ericifolia swamp (Hidden Swamp) at GR264264 is immediately behind the toe of the sand sheet and so would be expected to have similar nutrient levels and $\mathrm{pH}$ to that of Big Lagoon but, in contrast to Big Lagoon, the water here is intermittent. The vegetation at this site is a $M$. ericifolia tall open scrubland, having an understorey with patchy colonies of Carex appressa and other ground plants, such as Lilaeopsis polyantha, Hydrocotyle hirta, Leptinella longipes, Aira sp, Lobelia alata, Pteris tremula, Agrostis aequata, Bromus diandra, Senecio hispidulus and some Gahnia trifida.

The wetlands associated with the acid sands are notably depauperate in species, although this varies to some extent with size and water permanency. Intermittent wetlands have floors colonised by "damp" species and are fringed or occupied by $M$. ericifolia (and $M$. squarrosa to a lesser degree). The bases of large Melaleuca trees in the permanent water have a moss stocking above the water level, which supports a proliferation of Schizaea fistulosa. Restio tetraphyllus and Gahnia grandis are common and occur in the zone of most frequent or permanent inundation. Fringing these lagoons are usually dense scrub thickets with Gleichenia microphylla, Melaleuca spp., Gahnia grandis and Empodisma minus. The only plants recorded in the aquatic zone were Utricularia lateriflora, Restio tetraphyllus and Cryptostylis subulata. Smaller lagoons are fringed with Lepyrodia, which also dominates the swales in the sedgelands.

Emerald Swamp is the single largest swamp on the island; it is an acid paperbark swamp forest, which most closely fits the C3 Coastal swamp Forest classification of Pannell (1992), because it contains the prescribed dominants $M$. ericifolia and Acacia melanoxylon but almost none of the common species meant to typify the community, although other species are common (e.g. Schizea fistulosa) (pl. 6).

The melaleucas at Emerald Swamp are of similar diameter at breast height (dbh) and height to those at Hidden Swamp; therefore, presumably, both are of the same age since last fire. While there are differences in the permanency of water, some obvious floristic differences are apparently related to other edaphic factors, such as nutrients and $\mathrm{pH}$. Both Big Lagoon and Hidden Swamp were rich in wetland or herbaceous species, whereas at Emerald Lagoon and other acid wetlands the flora of the aquatic zone was confined to a few species (all absent from the wetlands on the calcareous sands). Few terrestrial species were recorded. Gahnia trifida is replaced at Emerald Swamp by $G$. grandis, and $S$. fistulosa, abundant in Emerald Swamp, was not 


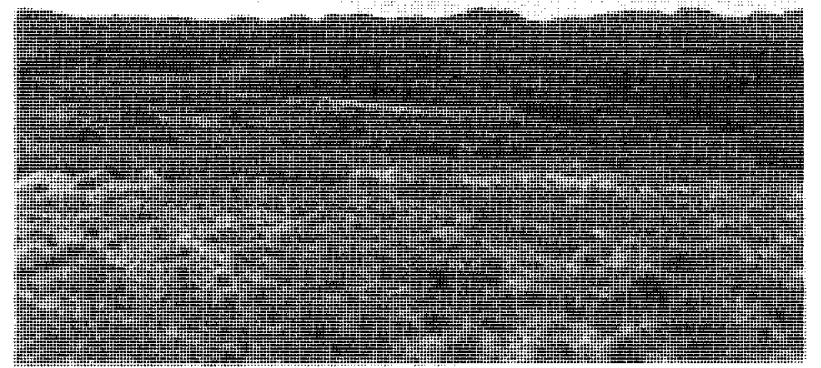

PLATE 5

View over the coastal scrub and grassland on the southwest of the island, with Hunter Island in the distance.

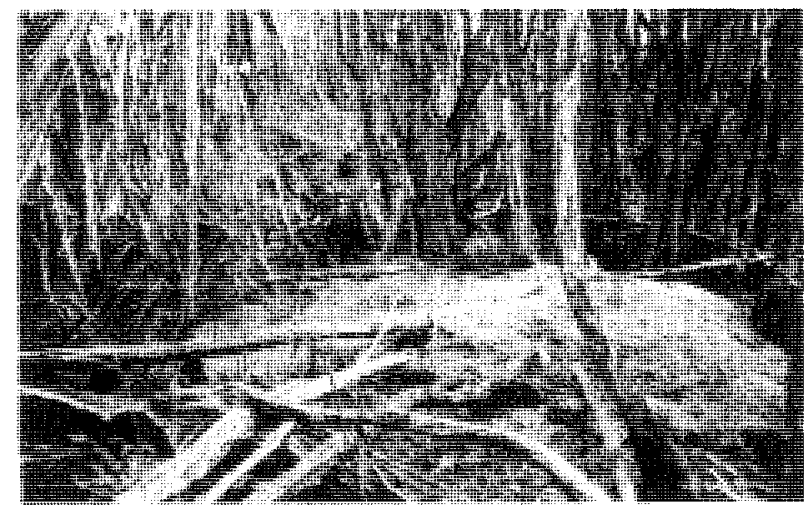

PLATE 6

Inside the Melaleuca forest in Emerald Swamp. At this locality, near the edge of the swamp, there are Sphagnum beds with numerous Schizaea fistulosa.

recorded from Hidden Swamp or the other wetlands on the calcareous sands.

Some lagoons have dried up. Minnetonka Lagoon is the most remarkable example of these. This lagoon is blocked by sand dunes, which were cleared late in the 1800 s for pasture (R. Alliston, pers. comm.). Its history is not recorded, but the presence of dead stags of tea-trees (either Melaleuca or Leptospermum) suggests that it was a swamp forest in the past. Since the death of the trees prior to 1951 (R. Alliston, pers comm.), there has been some severe erosion on the upper slopes of the basin, evidenced by the rree roots which are now $100-200 \mathrm{~mm}$ above the ground surface. An accumulation of sands has been deposited in the dry basin floor, and these support the pioneer species Carpobrotus rossii, Centrolep is monogyna, Gnaphalium spp, Sagina apetala, Crassula sieberana ssp. sieberana and Schoenus. The herbaceous species are the only species to occupy the freshly accumulated sands on the upper margins of the basin but are replaced in importance by the shrubs Olearia glutinosa, Melaleuca ericifolia, Senecio glomeratus and Apalochlamys spectabilis on the basin floor. The absence of plants larger than $1 \mathrm{~m}$ in height within the basin suggests recent fires or some other factor that has caused the vegetation to be no older than three years. Yet, the surrounding vegetation leading into the basin has not been

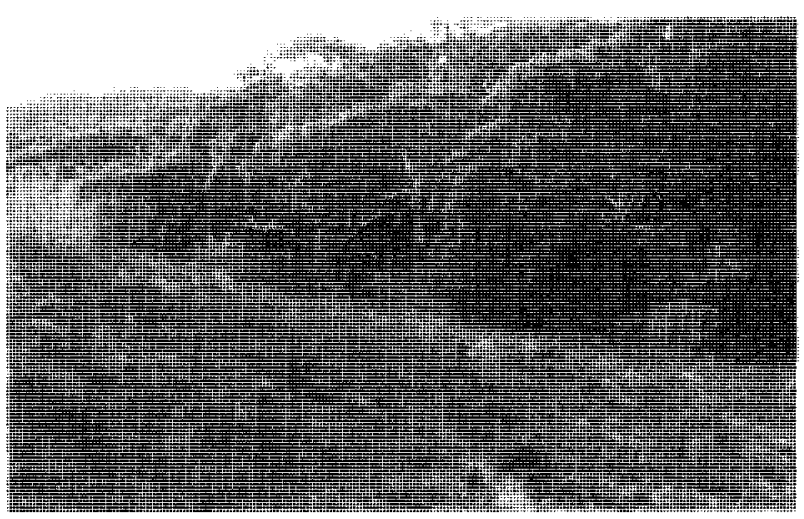

\section{PLATE 7}

The boundary between pasture on calcareous sands and eucalypt forest on acidsands. The only remnants of Eucalyptus viminalis forests in this locality southeast of Granite Hill are a few E. viminalis occurring on the edge of the calcareous sand sheet.

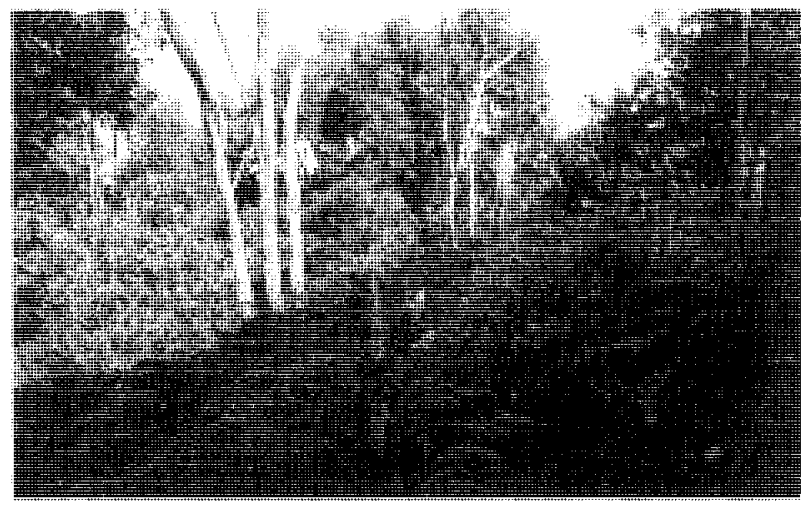

PLATE 8

Eucalyptus nitida woodland on the eastern flank of North Hummock. Pomaderris forms a patchy mid layer and bracken comprises a dense understorey.

burnt for at least 23-28 years (derived from nodal counts on Banksia marginata), plenty of time for plants of tree height to establish, and there are, at present, abundant tree seedlings throughout the basin floor.

\section{Eucalyptus viminalis Woodland and Forest}

This vegetation type occupies 30 ha or $<1 \%$ of the island It is restricted to the marine coastal sands which have mostly been cleared for pasture. The E. viminalis forests appear to coincide very closely with the cleated pasture areas on the southern part of the island (pl. 7). It is not possible to check this entirely, but the boundary between the E. viminalis community on the sand and $E$. nitida communities on the acid granite soils were found in three situations where a continuous eucalypt cover still existed across these substrates.

The $E$. viminalis forests and woodlands tend to be more open and less tangled than the other eucalypt communities on the island. They are grassy and shrubby and have a relatively high species diversity. At site 52 (GR207169), umbrageous $E$. viminalis has a patchy mid layer of Myoporum insulare, Melaleuca ericifolia, Acacia melanoxylon and A. verticillata with Olearia glutinosa and Leptospermum laevigatum as minor components. The understorey includes 
Pteridium esculentum, dense Poa poiformis, Dianella tasmanica, Pterostylis sp., Oxalis corniculata, Hydrocotyle hirta, Cerastium glomeratum, Viola hederacea, Bursaria spinosa, Luzula flaccida, Monotoca glauca, Drosera peltata and Isolepis nodosus.

A few scattered $E$. viminalis also occur on deeper soils around the eastern side of South Hummock where they occupy forests dominated by E. nitida and E. ovata.

\section{Eucalyptus nitida Forests}

Eucalyptus nitida occurs extensively over the island on the acid sands. In all, these forests occupy 1857 ha or $25 \%$ of the island's vegetation. E. nitida occurs as scattered individuals emergent within the wet sedgeland heath, as an emergent at varying densities over the Leptospermum scoparium-Banksia marginata scrub and as a forest dominant of wet eucalypt forest where it may co-occur with $E$. brookeriana and $E$. viminalis. The latter forests occur on the deepest loam soils, which have developed in areas topographically protected from high fire frequencies. They occur on the southern and eastern slopes of South Hummock and North Hummock and in the deep gullies on the island.

Trees can reach up to $35 \mathrm{~m}$, but are typically múch shorter. The understorey of the taller forests varies from pure Olearia argophylla patches, with only Pteridium and Coprosma in the ground layer, to a diverse open scrub layer of Acacia species, Melaleuca ericifolia, Bursaria spinosa, Monotoca glauca, Cyathodes juniperina and Leucopogon australis, and a lower ground layer of Pimelea linifolia, Coprosma quadrifida and the climber Clematis aristata. The ground is covered with a thick layer of litter, but a variety of herbs occur sparsely, including Geranium potentilloides, Drymophila cyanocarpa, Dianella tasmanica, Pterostylis sp. and other orchids. Along the drainage lines, Histiopteris incisa and Gahnia grandis are more frequent and the ferns Dicksonia, Phymatosorus and Pteris tremula occur only rarely.

On the eastern slopes of North Hummock (pl. 8), Pomaderris apetala replaces Olearia argophylla as the major understorey dominant, and the ground layer includes Lepidosperma elatius.

In more frequently burnt and recently burnt areas, the ground layer includes Poa poiformis, which is typically sparse but can form a dense cover in places. Boronia anemonifolia also occurs in recently burnt forests and survives at least 25 years.

A transition exists between $E$. nitida forests and scrub communities, the eucalypts reducing in height as they approach more frequently burnt and recently burnt areas, and as they approach the coast. They are replaced by Melaleuca ericifolia tall scrub before the coast is reached, dropping out more quickly on the exposed ridges but getting closer to the coast in the gullies. They are also replaced by $M$. ericifolia swamp forest in areas of permanent water logging.

In the absence of fire, these forests are likely to replace the scrub communities. They are also likely to become progressively more open with time, given the relatively short life spans of many of the component scrub species: Acacia verticillata is likely to live only 50 years and the other Acacia species less than 130 years. Some examples of continuous regeneration were evident in older $E$. nitida forests with $M$. ericifolia scrub understoreys. In such forests there is sufficient light generated by canopy gaps to allow
M. ericifolia seedlings to establish and grow to maturity. This has been observed in the swamp forests of northwestern Tasmania (Gibson et al. 1987).

\section{Rookeries}

The area occupied by seabird rookeries has not been determined but the locations of the larger rookeries are shown in figure 3. Most rookeries have been cleared by firing. The ferrile soils are usually sandy and high in phosphates, making them alkaline whether they occur in granite or marine-derived sand. Some rookeries are intact and support dense vegetation dominated by Poa poiformis tussock grassland or Carpobrotus rossii-Tetragonia implexicoma-Rhagodia candolleana succulent mat herbfield. Plants requiring groünd disturbance are common. These include mainly native composite herbs but also many exotic species. The native species include Apalochlamys spectabilis, Senecio odoratus, S. glomeratus, S. hispidulus, Urtica incisa and Sambucus gaudichaudiana. There is a convergence of species composition in rookeries on old marine (alkaline) sands and granite-derived sands.

A few rookeries in more inaccessible parts of the coast occupy wooded habitat. An example of one of these is at site 46 (GR256191), where Melaleuca ericifolia scrub occurs with some open patches with $P$. poiformis tussock grass cover of $80 \%$ projective foliage cover. The soils are sandy loam. Rhagodia candolleana occurs in patches, and other species are Senecio spp., Hydrocotyle, Parietaria debilis, $T$. implexicoma, Sambucus gaudichaudiana, U. incisa, Carex appressa and Eucalyptus nitida.

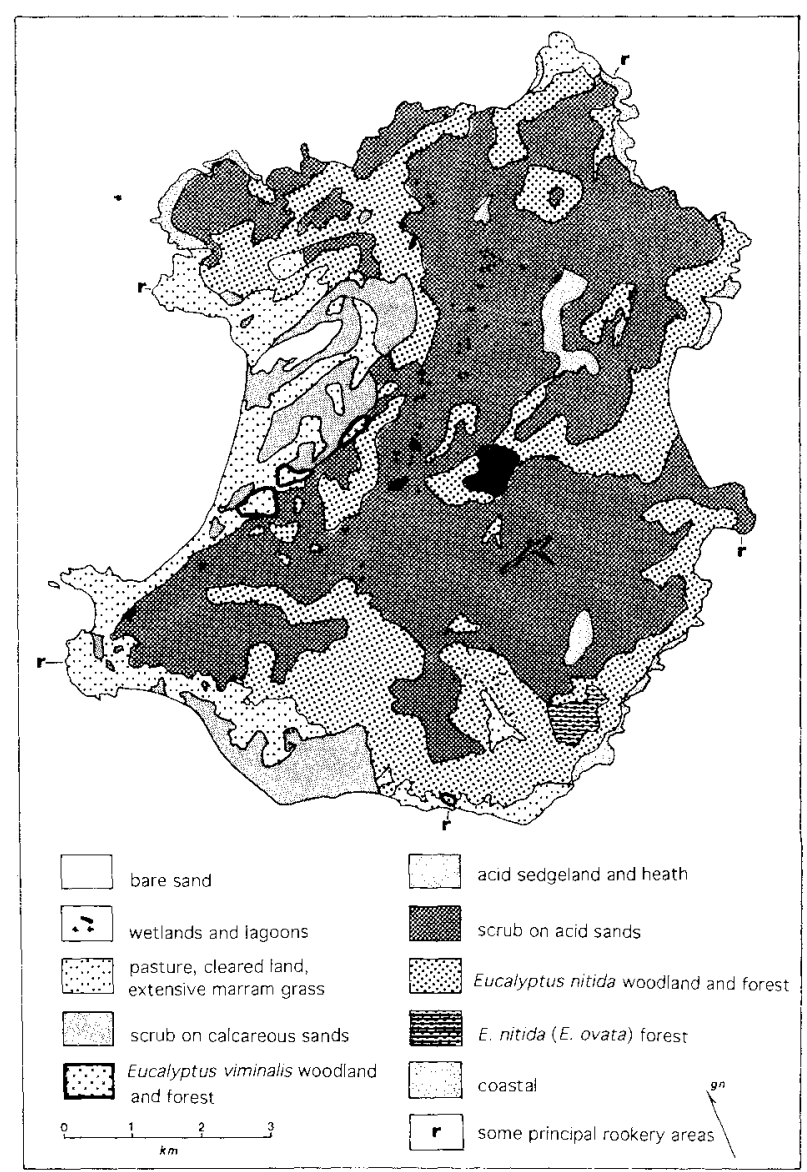

Fig. 3 - Vegetation of Three Hummock Island. 


\section{Pasture and other Modified Areas}

Much of the stabilised calcareous sand dunes have been modified for use as pasture for cattle and sheep grazing. The mapped area comprises 688 ha or $9 \%$ of the island and includes extensive areas dominated by Ammophila arenaria, which in the past have largely been maintained by fire for grazing purposes. Some areas have been cleared and sown with introduced species, top-dressed with superphosphate, cobalt and copper. Cerastium, Trifolium, various introduced grasses and a rich variety of other exotic species dominate these areas. Areas of the sand dunes that have been cleared and fired, but not top-dressed or sown with improved pasture species, are now dominated by Poa poiformis on the exposed slopes and on the lee of the slopes by Pteridium and Isolepis nodosus co-dominant with Poa poiformis. A rich variety of native and introduced herbs are characteristic of this vegetation. Native species include Ajuga australis, Geranium solanderi, Urtica incisa, Dichondra repens, Schoenus apogon, Crassula sieberana and Apium prostratum. Common exotics include Cirsium arvensis, Hypochoeris radicata, Acetosella vulgaris, Bellis perennis, Oxalis species, Holcus lanatus, Trifolium, Cotula coronopifolia, Calandrinia calyptrata and Arctotheca calendula.

Areas no longer being heavily grazed are now being invaded by pioneering shrubs, such as Cassinia aculeata with winddispersed seed, Melaleuca ericifolia, which, presumably, is also wind-dispersed, and species with long-lived seed stored in the soil, like Acacia melanoxylon and A. verticillata.

In addition to the pastures, three other areas have been cleared for airstrips, the one at Chimney Corner doubling as a grazing paddock. The area around the houses has garden plants.

\section{Coastal Vegetation}

Coastal vegetation comprises sand dune grasslands and shrublands, ephemeral herblands, sedgy and grassy herbfields on sand or peat, coastal heath, shrublands, scrub and grassland. Coastal vegetation as mapped includes low formations directly influenced by coastal processes. This mapping unit comprises 122 ha or $2 \%$ of the island.

The area influenced by coastal processes will be larger on an island because of greater exposure to onshore winds from any direction.

The coastal environment on Three Hummock Island can be divided into sandy coasts and rocky coasts. About $10 \mathrm{~km}$ of sandy coast occurs, mainly behind East and West Telegraph Beaches and Sandy Spit. On East Telegraph Beach (GR258198), a zonation across a berm, swale and foredune was observed: beach:unvegetated $\gg>$ front and summit of berm: Ammophila arenaria (associated species Carpobrotus rossii, Daucus glochidiatus) $\gg>$ rear of berm: $A$. arenaria (associated species - Isolepis nodosus, C. rossii, Stackhousia spathulata, Actites megalocarpa, Ozothamnus turbinatus) $\gg>$ swale: $O$. turbinatus (associated species many herbs including $C$. rossii, D. glochidiatus, A. megalocarpa, Lepidosperma gladiatum, Dichondra repens, S. spathulata and some herbaceous weeds) >> foredune slope: Ammophila arenaria comprises a third of the ground cover and the remainder is patches of various shrubs such as $O$. turbinatus, Correa backhousiana, Myoporum insulare and Leucopogon parviflorus. Lepidosperma gladiatum is a major dominant in this zone.

The zonation along the more exposed West Telegraph Beach differs from that at East Telegraph. Many zonal sequences exist along the beach and, although a uniform sequence could theoretically evolve along the beach in the absence of disturbance, this will not happen because of the dynamic nature of the habitat, which is subject to frequent (more so than the east coast) disturbances, such as storm events (having various effects on sand erosion and deposition, and salt accumulation), fires and wind erosion. Therefore, many stochastic and episodic events cause a scrambling of vegetation patterning. However, logical zonal sequences occur based on species responses to environmental factors.

Smaller beaches on the sheltered southern and southeastern part of the island are more protected from storms and also fire, both because of steep slopes to the rear of the beaches and also because they are less likely to be used as frequent boat anchorages, which are often associated with onshore fires. On these smaller beaches, there is a very dense shrubbery of C. backhousiana, with Melaleuca ericifolia to landward. The Melaleuca forms a narrow discontinous zone around the steeper parts of the coast between the distinctive zone of coastal species and the eucalyptdominated formations (pl. 9).

Many microhabitats occur around the coast. Small herbfields and grassy herbfields occur on patches of perennially wet ground at groundwater soaks or at the mouth of streams. At the northern end of West Telegraph Beach, for example, there is a sedgy herbfield in a damp swale. This herbfield forms a complete ground cover comprising Carex breviculmis, C. appressa, Lilaeopsis polyantha, Plantago coronopus, Isolepis nodosus, Apium prostratum, Selliêra radicans, Samolus repens, Schoenus nitens, Hydrocotyle muscoides, Gratiola latifolia and Eleocharis acuta.

The rocky granite shores present a diversity of microhabitats with varying levels of shade, exposure, moisture availability and susceptibility to invasion by exotics. Shady moist crevices may contain Asplenium obtusatum or Lobelia alata. Gravel chutes or rocky crevices at high-water mark may have Sarcocornia quinqueflora. The tops of large boulders or tors may have bird-dispersed species such as Alyxia buxifolia, Cyathodes juniperina and the exoric

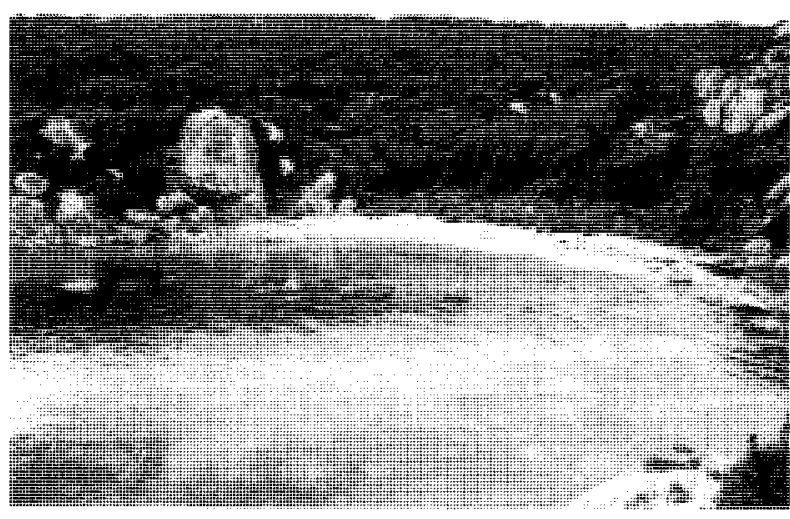

\section{PLATE 9}

A small bay on the east coast, south of Cape Rochon. Eucalyptus nitida scrub is visible on the skyline behind a coastal belt of Melaleuca ericifolia dominated scrub. Wind pruning of the scrub is evident at the head of the bay. Stipa stipoides tussocks are visible at the edge of the beach. 
Coprosma repens. On headlands and exposed rocky shores, Stipa stipoides frequently dominates a zone, which may be mainly bare rock and with plants in crevices and on small peacy lenses. These may include Samolus repens, Sarcocornia quinqueflora, Luzula flaccida, Juncus kraussii and Limosella lineata. Where Correa backhousiana and Cyathodes juniperina occur together, the latter can be highly wind pruned, while Correa backhousiana does not become wind pruned at all and its growing tips seem to be unaffected by salt winds relative to Cyathodes.

\section{THE FLORA}

There are 289 taxa of vascular plants from 80 families recorded for the island. There are 60 introduced species. Only two species are endemic to Tasmania. The island has a similar number of plant species to Clarke Island ( $8230 \mathrm{ha}$ ) in Eastern Bass Strait, which is a similar size to Three Hummock Island and a similar distance from the mainland of Tasmania. Clarke Island has 266 native species (Harris \& Reimer 1994). The compositions of their respective floras differ. The northwestern islands, in general, appear to have a flora with stronger Tasmanian affinities (J.B. Davies, pers. comm., S. Harris, pers. obs., Hope 1978). This could be explained by the relatively greater isolation from the mainland of King Island and the distance between King Island and the islands of the Hunter Group. There is no archipelago of islands connecting mainland Australian and Tasmanian floras such as occurs in Eastern Bass Strait, where dispersal may be more easily affected between the islands of the Curtis, Hogan, Kent and Furneaux Groups. Clarke Island exists close to Cape Barren Island, which is much larger than the nearest islands to Three Hummock. The deepest part of Bass Srrait separates King Island from Cape Otway (Blom 1988). Blom suggested that during the last glacial, Bass Strait was replaced by a saline lake bounded by a ridge to the east (Bassian Rise) and a lower ridge to the west (King Island/Mornington Peninsula Basement Ridge). As the sea level rose during the post-glacial transgression, the deeper sill north of King Island was flooded first about 10000 years
BP. The Bassian Rise was flooded at approximately 8000 years BP. Western Bass Strait has provided a greater barrier to latitudinal plant dispersal than Eastern Bass Strait because of the greater length of separation between Victoria and King Island.

In terms of island bigeography theory (MacArthur \& Wilson 1967), the number of species recorded is consistent with the species area relationship (fig. 4). An interesting comparison can be made between the islands of similar size in figure 4. Schouten Island has more species than the islands in the group of nearest size. Three Hummock and Hunter Islands are poorer in species, whereas Clarke Island is intermediate in richness. Both Clarke and Schouten Islands have greater habitat diversity. Schouten Island has the greatest variety of substrate types, including dolerite, and is situated in an identified centre of endemism

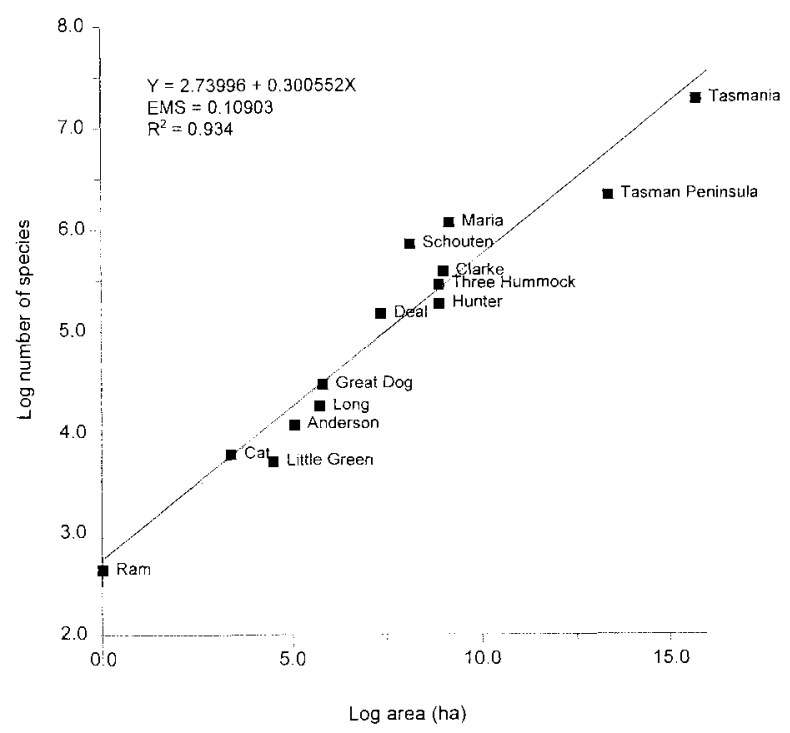

Fig. 4-Regression of number of plant species on area from 13 islands in Bass Strait and eastern Tasmania. Values for Tasman Peninsula and Tasmania are included for comparison.

TABLE 1

Geographical and floristic comparisons: Three Hummock Island and Clarke Island

\begin{tabular}{lll}
\hline Attribute & Three Hummock Island & Clarke Island \\
\hline area (ha) & 7284 & 8230 \\
latitude & $40^{\circ} 25^{\circ}$ & $40^{\circ} 31^{\prime}$ \\
longitude & $144^{\circ} 55^{\circ}$ & $148^{\circ} 15^{\prime}$ \\
av. ann. rainfall & $939 \mathrm{~mm}$ & $\approx 616 \mathrm{~mm}^{*}$ \\
mean no. of annual raindays & 208 & $\approx 133^{*}$ \\
temperature: & $13-20^{\circ} \mathrm{C}$ & \\
av. summer min. and max. (Feb.) & & \\
temperature: & $8-12.9^{\circ} \mathrm{C}$ & $\approx 8.6-20^{\circ} \mathrm{C}^{*}$ \\
av. winter min and max. (July) & & \\
total no. of native vascular & 229 & 266 \\
plants recorded & 60 & $42.8^{\circ} \mathrm{C}^{*}$ \\
no. of introduced plants & 72 & 75 \\
no. of native plant families & 2 & 6 \\
no. of Tasmanian endemic plants & 0 & 6 \\
plant spp. at southern limit & & \\
\hline
\end{tabular}

* Records obtained from nearby Swan Island. 
(Kirkpatrick \& Brown 1984), which is known for the particular association of endemics with the dolerite substrate. The island also has much greater relief than Clarke and Three Hummock Islands, thereby allowing more habitat niches to be sustained.

Mediterranean climate landscapes in the Southern Hemispere such as the South West Botanical Province of Western Australia and the Cape Fynbos of South Africa have a higher floristic diversity than areas with cool temperate climates (Nelson 1981). Although Three Hummock Island and Clarke Island share equivalent temperature ranges, Clarke Island is considerably drier (table 1), with greater evapotranspiration due to more cloud-free days and a climate which approaches the characteristics of a Mediterannean climate.

It is clear that both Hunter and Three Hummock Islands are relatively poorer in species than the islands of eastern Tasmania. Both Hunter and Three Hummock Islands have low geological diversity. Hunter Island is mostly quartzite with old, unconsolidated sands. Three Hummock Island, in addition, is very uniform in habitat with only two major substrate types: acid sandy and gravelly granitederived substrates and alkaline sands of marine origin, as well as a small number of habitat types. In the past, the basalt has been cleared, cultivated and ploughed. Clarke Island is only slightly more diverse, containing Silurian metasediments, granite, calcareous marine sands and calcarenite. Even Deal Island, which is smaller than Three Hummock Island and Hunter Island, and is more remote from larger land masses, has a relatively rich flora in comparison to the Hunter Group Islands. Tasman Peninsula (Brown \& Duncan 1989) and Little Green Island (S. Harris and A.M. Buchanan, pers. obs.) are shown to be speciespoor in relative terms. Looking further than the high correlation of species numbers and island size, explanations for the relative numbers of species amongst these islands may be found in any number of other factors, such as climate, relative proximity to other islands and land masses, degree of human modification, time since isolation, and proximity to centres of endemism and palaeogeographic refugia. Furthter work is necessary on data from all Tasmanian offshore islands before the role of these factors is clarified.

Calcarenite (or Tertiary limestone) is absent from Three Hummock Island but occurs on King Island. Yet only on limestones in eastern Bass Strait do southern Australian Mediterranean climate species, such as Threlkeldia diffusa and Zygophyllum apiculatum occur. Nor do the Eremean elements, which occur in eastern Bass Strait (Harris \& Davis 1995), occur in western Bass Strait. These elements include Sicyos australis, Gyrostemon thesioides, Frankenia pauciflora, Ixiolaena supina, Lavatera plebeia and Calytrix tetragona. Some drought tolerant and widespread species are conspicuously absent in western Bass Strait (Harris $\&$ Davis 1995). The drought tolerant Callitris rhomboidea, for example, is absent from western Bass Strait, even though it occurs at Cape Nelson (fig. 1) on the southwestern coast of Victoria. Additionally, the widespread (in warm southern coastal Australia), drought-hardy, exotic grasses Catapodium rigidum, Parapholis incurva and Hainardia cylindrica, similarly widespread in the Furneaux Group, are not known from western Bass Strait islands.

It is possible that more detailed floristic and climatic analyses will show that the eastern extremity of the southern Australian Mediterranean climate envelope takes in northern
Bass Strait but widens towards the east with a bifurcation at the eastern extremity of Bass Strait. The northern arm extends up the extreme eastern coast of Victoria around Croajingalong National Park, and the southern arm includes the extremities of northeastern Tasmania and central eastern coastal Tasmania. Where this climatic envelope is coincident with siliceous soils, there are species belonging to otherwise South West Western Australia Botanical Province genera which fit within the eastern extremes of this environmental envelope. Conospermum taxifolium sensu lato (Proteaceae) is a good example. It occurs on sandy substrates from Freycinet Peninsula to St Helens and at Croajingalong National Park.

Comparing the species list from this study with that of Cameron (1984) from the heathland and scrub around Ordnance Point in northwestern Tasmania, indicates that Three Hummock Island flora is a depauperate subset of the northwestern Tasmanian coastal and near coastal flora.

\section{GENERAL DISCUSSION}

The vegetation of Three Hummock Island has changed a lot since the cessation of extensive grazing activity on the island in the $1970 \mathrm{~s}$. Areas that were formerly open shrubland and grassland are now heavily colonised by scrub, mostly dominated by Leptospermum laevigatum. These areas provided the main grazing runs for cattle and were burned every year (J. Alliston, pers. comm.). On the siliceous acid sands and gravels over the granite, extensive fires maintained the vegetation as heath and sedgeland. Eucalyptus nitida is heavily coppiced and the diameter of the underground lignotuber is estimated in some cases to be up to $3 \mathrm{~m}$ in diameter. This eucalypt can survive a high fire frequency although it is an element of the taller eucalypt forests in the more fire protected parts of the island.

The most extensive fires in recent times occurred in 1982 and burnt across most of the island. Subsequent fires in 1984 "burnt out country which was missed in the 1982 fires" (R. Alliston, pers. comm.). The areas of taller eucalypt forest and Emerald Swamp were missed by these fires, but elsewhere the counting of growth nodes on Banksia marginata most often gave ages consistent with germination following fires in 1982 or 1984 . On the sand plains behind West Telegraph Beach in 1976, there was extensive Banksia (and L. laevigatum) savannah shrubland which, since the cessation of grazing, has been colonised in the intervening spaces by regrowth comprising mainly Banksia but also including L. Laevigatum, Leucopogon australis and Olearia glutinosa. The older Banksia trees are now $8 \mathrm{~m}$ tall. In one locality near the south coast, banksias of this height with a $\mathrm{dbh}$ of approximately $0.3 \mathrm{~m}$ gave inferred ages of around 40 years, where they were associated with a small patch of E. viminalis $(0.20-0.25 \mathrm{~m} \mathrm{dbh}, 8 \mathrm{~m} \mathrm{ht})$. Remnants of bush with inferred ages berween 35 and 40 years old were encountered in various places, indicating extensive major fires somewhere between 1955 and 1960 .

The exotic species recorded are mostly of agricultural origin and are typically grasses or clovers sown in developed areas, as well as ubiquitous weeds such as Sonchus oleraceus, Cerastium glomeratum and Hypochoeris spp. Around the buildings at Chimney Corner are old shelter tree plantings these mainly consisting of Cupressus macrocarpa, Pinus radiata and Araucaria heterophylla. Lycium ferocissimum, which was probably introduced as a windbreak has now 
grown into thickets near the homesteads. An exotic tree grows at the Spring (Salix sp.). On the coast, Senecio elegans, Euphorbia paralias and Ammophila arenaria are the most striking introductions. Senecio elegans is more firmly established on the dunes of the western side of Three Hummock Island than anywhere else in Tasmania. Apart from growing occasionally on the strand line, the best development was observed to be on the north faces of dunes, especially in the disturbance zone around penguin burrows. The long-term effect of this introduction on native plant communities (at present it occurs amongst marram grass) is not known, but certainly the common name "elegant groundsel" is justified by the blaze of purple in early October. Marram grass (A. arenaria) occurs around the coast, effectively stabilising the youngest dunes at Chimney Corner and the berm and primary dune face at East Telegraph Beach.

\section{Vegetation Management}

Weeds

Weeds have been introduced over a long period of occupation of the island. Most of the weeds are concentrated around rookeries, where soil fertility and ground disturbance is maximised. The pasture grasses and associated weeds are found throughout the calcareous sandy areas which were preferentially cleared for pasture development. The coastal zone is exposed to sea-borne seed introductions (e.g. Euphorbia paralius). Weed control on the island would be expensive. Therefore, only those which pose a pernicious threat to nature conservation values should be targetted for control or eradication.

The establishment of $E$. paralius on the coast should be prevented. It is capable of aggressive colonisation of berms, foredunes and coastal herbfields, and has the potential to displace native species, particularly in the latter habitat. The seed source for these plants is likely to come from both the west and the east (see Harris \& Kirkpatrick 1996) according to seasonal sea current flows. Establishment in this nature reserve would provide a reservoir of propagules which could invade much northwestern and western coastline.

The thistles Carduus pycnocephalus and Cirsium vulgare are prevalent in Ranger Rookery, where they form dense patches. The Ranger Rookery had been burnt more recently than any others. Burning the rookeries will encourage weeds such as thistles. Rookeries do not need to be burned at all. They can exist in association with dense tussock grass or in a shrubby or scrub understorey.

The concentration of exotics around the buildings at Chimney Corner need not be a management problem. African Boxthorn (Lycium ferocissimum) is the exception. Planted on many Bass Strait islands last century, it was an excellent wind break. If left uncontrolled it can spread and form large patches of impenetrable scrub and completely suppress other vegetation. Birds spread the seeds, which exacerbates the problem.

\section{Plant dieback}

Symptoms consistent with cinnamon fungus (Phytophthora cinnamomi) mortality were observed in scattered small patches on the island.

Even if the fungus was determined to be present on the island, it is difficult to envisage appropriate measures to prevent its spread or to see whether control of spread would have any significant effect on the vegetation. There is an apparently low diversity of plants on the island which are susceptible to the fungus at the population level. It is possible that the fungus may have already run its course on the island and depleted populations of susceptible plants such as Epacris lanuginosa in some habitats.

\section{Fire Management}

The purpose of fire management is to maximise flora diversity and long-term survival of component species. It is clear that the island has been dominated by scrub vegetation for at least as long as the island has been known by Europeans. Fire is required as part of the management regime for the island, because most of the communities require fire. We suggest some areas should remain unburnt for long periods. Fire exclusion areas should include the rookeries, much of the coastal vegetation, wetland and wetland perimeter vegetation and some patches of taller forest and dune scrub. A fire management plan is required for the island.

\section{ACKNOWLEDGEMENTS}

We dedicate this paper to Commander John Alliston and Eleanor Alliston and their family, residents of Three Hummock Island since 1951, who originally advocated the purchase and reservation of the island by the Government, as a nature reserve. We thank Alex Buchanan and Dennis Morris of the Tasmanian Herbarium for checking our species identifications and identifying many of the difficult specimens. We also acknowledge the assistance of Neville Walsh for checking through the Melbourne Herbarium collection for specimens from Three Hummock Island. Dr Irynej Skira and Dr Adrian Pyrke assisted in various ways.

\section{REFERENCES}

AluISTON, E., 1966: ESCAPE TO AN ISLAND. Heinemann, London.

A.O.T. (Archives Office of Tasmania). Correspondence file, Three Hummock Island. Extract from the English translation of Garibaldi's autobiography "Memorie Autografiche". Published in English by Werner 1889 and quoted in a letter from G. Farmer, Hellyer Regional Librarian, 29 January 1969 to Mrs E. Alliston.

Atkinson, E.D., 1890: Notes of a short trip to the islands of western Bass Straits. Vict. Nat. 6: 156-164.

BLOM, W.K., 1988: Late Quaternary sediments and sea-levels in Bass Basin, southeastern Australia - A preliminary report. Search 19(2): 94-96.

BOwDLER, S., 1980: Hunters and Farmers in the Hunter Islands: Aboriginal and European Land-use of north-wese Tasmanian islands in the historical period. Rec. Queen Vict. Mus. 70.

BRIGGS, J.D. \& LEIGH, J.H., 1988: RARE OR THREATENED AUSTRALIAN PLANTS. Spec. Publ. 14. Australian National Parks and Wildlife Service.

Brown, M.J. \& DunCan, F., 1989: The vegetation of Tasman Peninsula. In Smith, S.J. (Ed.), 1989: IS HISTORY ENOUGH? PAST, PRESENT AND FUTURE USE OF THE RESOURCES OF TASMAN PENINSULA. Royal Society of Tasmania, Hobart: 33-50. 
BuChanan, A.M., 1995: A census of the vascular plants of Tasmania. Tasm. Herb. Occ. Publ. 5.

Bureau of METEORology, 1996: Report on climatic records for Currie, King Id., Swan Island and Three Hummocks Island. Tasm. and Antarctica Regional Office, Hobart. File 20/11/32(98).

CAmeron, M.P., 1984: The vegetation of Ordnance Point, Northwestern Tasmania. In Green, R.H. (Ed.): The vegetation, fauna and archaeology of Ordnance Point, north-western Tasmania. Rec. Queen Vict. Mus. 84.

Collins, D., 1802: AN ACCOUNT OF THE ENGLISH COLONY IN NEW SOUTH WALES. VOL II. (Republished by the Royal Australian Historical Society, Fletcher, B.H., Reed, A.H. \& Reed, A.W. [Eds]. Sydney 1975.)

CORNELL, C., (Ed.), 1974: THE JOURNAL OF POST CAPTAIN NICOLAS BAUDIN. Libraries Board of Sourh Australia.

CURTIS, W.M.C., 1979: THE STUDENTS FLORA OF TASMANIA. Part 4a. Government Printer, Hobart.

Flora Advisory COMMITTEe, 1994: NATIVE HIGHER PLANT TAXA WHICH ARE RARE OR THREATENED IN TASMANIA. Edn. 1. Species at Risk, Tasmania-flora. Parks and Wildlife Service, Tasmania.

Gibson, N., Williams, K., Marsden-Smedley, J. \& Brown, M.J., 1987: Regeneration characteristics of a swamp forest in northwestern Tasmania. Pap. Proc. R. Soc. Tasm. 121: 93-100.

Harris, S. \& Davis, G., 1995: The vegetation and flora of Deal Island, Kenr Group. Pap. Proc. R. Soc. Tasm. 129: 4351

Harris, S. \& Kirkpatrick, J.B., 1996: The coastal vegetation of Northeast Tasmania. In Mesibov, R. (Ed.): BIOGEOGRAPHY OF NORTHEAST TASMANIA. Rec. Queen Vict. Mus. 103: 121-131.

Harris, S. \& Reimer, A., 1994: Flora and Fauna of Clarke Island. Unpubl. Rep. Parks \& Wildl. Serv., Hobart: $44 \mathrm{pp}$.

Hope, G.S., 1978: The Late Pleistocene and Holocene vegerational history of Hunter Island, North Western Tasmania. Aust. J. Bot. 26: 493-514.

Jennings, D.J. 1976: Three Hummock Island. Unpubl. internal rep. to Chief Geologist, Hobart, 26 August 1976: 8pp.

Jennings, D.J. \& Cox, S.F., 1978: Geol. Atlas 1:250000 Ser. Sheet SK55-1,2. 1st Edn. KING ISLAND-FLINDERS ISLAND. Dep. Mines Tasm.

KirkPATRICK, J.B., 1977: THE DISAPPEARING HEATH. Tasmanian Conservation Trust Inc.

Kirkpatrick, J.B. \& Brown, M.J., 1984: The palaeogeographic significance of local endemism in Tasmanian higher plants. Search 15(3-4): 112-113.
Kirkpatrick, J.B. \& DiCKinson, K.J.M., 1984: VEGETATION MAP OF TASMANIA 1:500,000. Forestry Commission, Tasmania.

Kirkpatrick, J.B, \& Harris, S., 1995: The conservation of Tasmanian dry coastal vascular plant communities. Wildl. Sci. Rep. 95/1, Parks \& Wildlife Service, Hobart.

Kirkpatrick, J.B. \& HarwoOd, C.E., 1981: The conservation of Tasmanian werland macrophytic species and communities. Rep. Aust. Herit. Commn, Tasm. Conserv. Trust: $165 \mathrm{pp}$.

Kirkpatrick, J.B. \& Harwood, C.E., 1983a: The conservation of Tasmanian macrophytic wetland vegetation. Pap. Proc. R. Soc. Tasm. 117: 5-20.

Kirkpatrick, J.B. \& Harwood, C.E., 1983b: Plant communities of Tasmanian wetlands. Aust. J. Bot. 31: 437-451

LeEs, J.W., 1976: Proposed Three Hummock Island Nature Reserve. Unpubl. rep. Dir. Agric., Hobart, 14 May 1976: 3 pp.

Macarthur, R.H. and Wilson, E.O., 1967: THE THEORY OF ISLAND BIOGEOGRAPHY. Monogr. Popul. Biol. 1. Princeton University Press, N.J.

MCNAMARA, K.J., 1989: Summary report of CONCOM technical workshop on Island Management. In Burbidge, A.A. (Ed.): AUSTRALIAN AND NEWZEALAND ISLANDS: NATURE CONSERVATION VALUES AND MANAGEMENT. Proceedings of a technical workshop, Barrow Island, Western Australia, 1985. Occ. Pap. 2/89. CALM, WA.

Mueller-Dombols, D. \& EllenberG, P., 1974: AIMS AND METHODS OF VEGETATION ECOLOGY. Wiley, New York

Nelson, E.C., 1981: Phytogeography of southern Australia. In Keast, A. (Ed.): ECOLOGICAL BIOGEOGRAPHY OF AUSTRALIA. Vol.1. Dr W. Junk, The Hague: 733-759.

PANnell, J.R., 1992: SWAMP FORESTS OF TASMANIA. Forestry Commission, Tasmania.

PLOMLEY, N.J.B., 1983: THE BAUDIN EXPEDITION AND THE TASMANIAN ABORIGINES 1802. Blubber Head Press, Hobart.

RICHLEY, L.R., 1984: LAND SYSTEMS OF TASMANIA REGION 1. A.B. Caudell, Government Printer, Hobart: $58 \mathrm{pp}$.

SPECHT, R.L., 1970: VEGETATION OF SOUTH AUSTRALIA. Government Printer, Adelaide.

Stockton, J., 1983: Fires by the seaside: Historic vegetation changes in northwestern Tasmania. Pap. Proc. R. Soc. Tasm. 116: 53-66.

WhitTAKER, R.J., 1995: Disturbed island ecology. Trends in Ecology and Evolution 10 (10) [112]: 389-430.

Zeigeler, D., Jones, D., Tonelly, P., Wapstra, H. \& Harris, S., 1996: Atlas of Tasmanian orchids. Unpubl. rep. Aust. Heritage Commn.

(accepted 12 November 1996) 


\section{APPENDIX \\ Higher Plant Census for Three Hummock Island}

Vouchers and other records:

$\mathrm{HO}=$ Voucher lodged at the Tasmanian Herbarium, Hobart;

MEL $=$ Voucher exists at the National Herbarium of Victoria, Melbourne.

Where a taxa was not recorded by ourselves but by others it is marked as follows:

${ }^{*} 1$ Recorded by Kirkpatrick \& Harwood 1981

*2 Recorded by P. Wells (Kirkpatrick \& Harris 1995)

*3 Recorded by R. Gunn in 1844, H. Atkinson 1888, D. Lang 1979 (Ziegeler et al.1996, Curtis 1979).

Conservation status codes (source: Flora Advisory Committee 1994):

$\mathrm{R}=$ Listed as rare at a national level (Briggs \& Leigh 1988); $\mathrm{V}=$ Vulnerable to extinction in Australia;

$r=$ Rare but not extinct, endangered or vulnerable taxa, where:

$\mathrm{rl}$ = Rare taxa that have a disrribution in Tasmania that does not exceed a range defined by a square measuring $100 \mathrm{X} 100 \mathrm{~km}$;

$\mathrm{r} 2$ = Rare taxa that occur in 20 or fewer 10 X $10 \mathrm{~km}$ Australian Map Grid Squares in Tasmania;

$\mathrm{r} 3=$ Rare taxa that do not fit $\mathrm{r} 1$ or $\mathrm{r} 2$, but which have very small and/or localised populations wherever they occur in Tasmania.

Distribution codes : $\quad i=$ introduced; $\quad E N=$ endemic to Tasmania (source: Buchanan 1995).

Community types: $\quad \begin{array}{ll}1 & =\text { Eucalyptus nitida forest } \\ 2 & =\text { Sctub on acid sands } \\ 3 & =\text { Sedgeland heath } \\ 4 & =\text { Acid wetlands } \\ 5 & =\text { Calcareous wetlands }\end{array}$

$$
\begin{aligned}
& 6=\text { Calcareous grasslands } \\
& 7=\text { Calcareous scrub } \\
& 8=\text { Eucalypus viminalis forest } \\
& 9=\text { Melaleuca swamp forest }
\end{aligned}
$$

\begin{tabular}{|c|c|c|c|c|c|c|c|c|c|c|c|c|c|c|c|}
\hline & \multirow{2}{*}{$\begin{array}{l}\text { Where } \\
\text { record- } \\
\text { ed }\end{array}$} & \multirow{2}{*}{$\begin{array}{c}\text { Status/ } \\
\text { distri- } \\
\text { bution }\end{array}$} & \multicolumn{13}{|c|}{ Community Types } \\
\hline & & & 1 & 2 & 3 & 4 & 5 & 6 & 7 & 8 & 9 & 10 & 11 & 12 & 13 \\
\hline \multicolumn{16}{|l|}{ DICOTYLEDONAE } \\
\hline \multicolumn{16}{|l|}{ AIZOACEAE } \\
\hline Carpobrotus rossii & $\mathrm{HO}$ & & & & & & $r$ & $r$ & & & & c & c & & \\
\hline Tetragonia implexicoma & $\mathrm{HO}$ & & o & & & & & o & $o$ & & & c & $c$ & o & \\
\hline T. tetragonioides & & & & & & & & & & & & $c$ & $\mathrm{c}$ & o & \\
\hline \multicolumn{16}{|l|}{ APIACEAE } \\
\hline Apium prostratum & $\mathrm{HO}$ & & & & & & o & $\mathrm{r}$ & & & & $c$ & 0 & o & \\
\hline Centella cordifolia & $* 1$ & & & & & & & o & & & & & & & \\
\hline Daucus glochidiatus & $\mathrm{HO}$ & & & & & & & o & & & & c & $c$ & 0 & \\
\hline Eryngium vesiculosum & $\mathrm{HO}$ & & & & & & c & & & & & & & & \\
\hline Hydrocotyle hirta & $\mathrm{HO}$ & & $c$ & $c$ & & & $r$ & c & & $\mathrm{c}$ & o & $c$ & $c$ & c & \\
\hline H. muscosa & $\mathrm{HO}$ & & & & & & c & c & & & o & $r$ & & r & \\
\hline Lilaeopsis polyantha & $\mathrm{HO}$ & & & & & & o & & & & & $\mathrm{r}$ & & & \\
\hline Xanthosia dissecta & & & & & $r$ & & & & & & & & & & \\
\hline \multicolumn{16}{|l|}{ APOCYNACEAE } \\
\hline Alyxia buxifolia & $\mathrm{HO}$ & & & & & & & & & & $r$ & 0 & & & \\
\hline \multicolumn{16}{|l|}{ ASTERACEAE } \\
\hline Actites megalocarpa & $\mathrm{HO}$ & & & & & & & o & & & & o & 0 & 0 & \\
\hline Apalochlamys spectabilis & $\mathrm{HO}$ & $\mathrm{r} 2$ & & & & & $\mathrm{r}$ & & & & & o & $c$ & r & \\
\hline Arctotheca calendula & $\mathrm{HO}$ & $\mathrm{i}$ & & & & & & c & c & & & & & c & \\
\hline Bellis perennis & $\mathrm{HO}$ & $\mathrm{i}$ & & & & & & & & & & & & $c$ & c \\
\hline Brachyscome diversifolia & $\mathrm{HO}$ & & & & & & & & & & & $r$ & & & \\
\hline Carduus pycnocephalus & $\mathrm{HO}$ & $\mathrm{i}$ & & & & & & o & & & & & & 0 & \\
\hline Cassinia aculeata & $\mathrm{HO}$ & & & o & & & & c & & & o & & o & 0 & \\
\hline Chrysocephalum apiculatum & MEL & & & & & & & r & & & & & & & \\
\hline Cirsium arvense & $\mathrm{HO}$ & & & & & & & c & o & & & o & o & c & \\
\hline C. vulgare & $\mathrm{HO}$ & $\mathrm{i}$ & & & & & & o & & & & & & & \\
\hline Cotula australis & $\mathrm{HO}$ & & & & & & & o & & & & & 0 & & \\
\hline C. coronopifolia & $\mathrm{HO}$ & $\mathrm{i}$ & & & & & c & c & & & & c & & & \\
\hline \multicolumn{16}{|l|}{ C. vulgaris } \\
\hline var. australasica & & & & & & & & $\mathrm{r}$ & & & & & & & \\
\hline Gnaphalium collinum & $\mathrm{HO}$ & & & & $r$ & & & c & & & & c & & & \\
\hline G. indutum & $\mathrm{HO}$ & & & & & & & & & & & 0 & & & \\
\hline
\end{tabular}

$$
\begin{aligned}
& 10=\text { Coastal vegetation } \\
& 11=\text { Rookery vegetation } \\
& 12=\text { Pasture } \\
& 13=\text { Horticultural plantings }
\end{aligned}
$$

Species abundance codes: $\mathrm{r}=$ rare; $\mathrm{o}=\mathrm{occasional} ; \mathrm{c}=$ common. 
Appendix cont.

\begin{tabular}{|c|c|c|c|c|c|c|c|c|c|c|c|c|c|c|c|}
\hline & \multirow{2}{*}{$\begin{array}{l}\text { Where } \\
\text { record- } \\
\text { ed }\end{array}$} & \multirow{2}{*}{$\begin{array}{c}\text { Status/ } \\
\text { distri- } \\
\text { bution }\end{array}$} & \multicolumn{13}{|c|}{ Community Types } \\
\hline & & & 1 & 2 & 3 & 4 & 5 & 6 & 7 & 8 & 9 & 10 & 11 & 12 & 13 \\
\hline Gnaphalium sp. & $\mathrm{HO}$ & & & & & & & $r$ & & & & I & & & \\
\hline Hypochoeris radicata & $\mathrm{HO}$ & $\mathrm{i}$ & $c$ & o & & & & $\mathrm{c}$ & $\mathrm{c}$ & & 0 & o & o & c & o \\
\hline Lagenifera stipitata & $\mathrm{HO}$ & & $\mathrm{r}$ & & & & & & & r & & $r$ & & & \\
\hline Leontodon taraxacoides & $\mathrm{HO}$ & $\mathrm{i}$ & 0 & & & & & & & & & & & & \\
\hline Leptinella longipes & $* 1$ & & & & & & o & & & & & & & & \\
\hline Leucophyta brownii & $\mathrm{HO}$ & & & & & & & & & & & o & & & \\
\hline Olearia argophylla & $\mathrm{HO}$ & & o & & & & & & & o & & & & & \\
\hline O. glutinosa & $\mathrm{HO}$ & & $r$ & & & & $r$ & & o & o & & o & o & & \\
\hline O. lepidophylla & $\mathrm{HO}$ & & & & & & $r$ & & & & & o & & & \\
\hline O. phlogopappa & $\mathrm{HO}$ & & $r$ & & & & & & o & & & & & & \\
\hline O. ramulosa & $\mathrm{HO}$ & & r & & & & $\mathrm{r}$ & & & & r & o & & & \\
\hline Ozothamnus ferrugineus & $\mathrm{HO}$ & & o & & & & & & & & & & & & \\
\hline O. turbinatus & $\mathrm{HO}$ & & & & & & & o & & & & c & o & r & \\
\hline Pseudognaphalium luteo-album & $\mathrm{HO}$ & & & & & & & & & & & o & o & o & \\
\hline Senecio biserratus & $* 2$ & & & & & & & & & & & & o & & \\
\hline S. elegans & $\mathrm{HO}$ & $i$ & & & & & & o & & & & o & 0 & & \\
\hline S. glomeratus & $\mathrm{HO}$ & & & & & & & & & & & o & & & \\
\hline S. hispidulus & $\mathrm{HO}$ & & & & & & o & & & & & o & o & o & \\
\hline S. lautus & $\mathrm{HO}$ & & & & & & & & & & & o & & & \\
\hline S. minimus & $\mathrm{HO}$ & & & & & & o & & & & & & & & \\
\hline S. odoratus & $\mathrm{HO}$ & & $\mathrm{r}$ & & & & & & o & & & o & & & \\
\hline Sonchus asper & $\mathrm{HO}$ & $\mathrm{i}$ & & & & & & o & $r$ & & & o & $c$ & c & \\
\hline S. oleraceus & $\mathrm{HO}$ & $\mathrm{i}$ & & & & & & & $\mathrm{r}$ & & & o & $\mathrm{c}$ & c & \\
\hline Taraxacum sp. & $\mathrm{HO}$ & $\mathrm{i}$ & & & & & & & & & & o & & & \\
\hline Vellereophyton dealbatum & $\mathrm{HO}$ & $\mathrm{i}$ & & & & & & o & & & & o & 0 & o & \\
\hline \multicolumn{16}{|l|}{ BRASSICACEAE } \\
\hline Cakile maritima & $\mathrm{HO}$ & $\mathrm{i}$ & & & & & & & & & & 0 & & & \\
\hline Cardamine gunnii & $* 1$ & & & & & & & & & & & r & & & \\
\hline C. paucijuga & $\mathrm{HO}$ & & & & & & & & & & & 0 & & & \\
\hline Lepidium flexicaule & $\mathrm{HO}$ & $\mathrm{R}, \mathrm{r} 2$ & & & & & & & & & & & & r & \\
\hline L. foliosum & $\mathrm{HO}$ & & & & & & & & & & & & o & o & \\
\hline Rorippa sp. & $\mathrm{HO}$ & $\mathrm{i}$ & & & & & & & & & & $\mathrm{r}$ & & & \\
\hline \multicolumn{16}{|l|}{ Callitrichaceae } \\
\hline Callitriche stagnalis & $\mathrm{HO}$ & $\mathrm{i}$ & & & & & c & & & & & & & & \\
\hline \multicolumn{16}{|l|}{ CAMPANULACEAE } \\
\hline Lobelia alata & $\mathrm{HO}$ & & & & & & r & & & & & o & o & & \\
\hline Pratia irrigua & $* 1$ & & & & & & o & r & & & & & & & \\
\hline P. surrepens & $\mathrm{HO}$ & & & & & & & o & & & & & & & \\
\hline Wahlenbergia littoricola & $\mathrm{HO}$ & & & & & & & o & o & & & o & o & o & \\
\hline Wablenbergia sp. & $\mathrm{HO}$ & & & & & & & o & & & & o & o & o & \\
\hline \multicolumn{16}{|l|}{ CAPRIFOLLACEAE } \\
\hline Sambucus gaudichaudiana & $\mathrm{HO}$ & & & & & & & & $r$ & & & 0 & c & r & \\
\hline \multicolumn{16}{|l|}{ CARYOPHYLLACEAE } \\
\hline Arenaria leptoclados & $\mathrm{HO}$ & $\mathrm{i}$ & & & & & & & & & & & & & o \\
\hline Cerastium glomeratum & $\mathrm{HO}$ & $\mathrm{i}$ & & o & & & & c & c & r & & o & o & c & \\
\hline \multicolumn{16}{|l|}{ Colobanthus apetalus } \\
\hline var apetalus & $\mathrm{HO}$ & & & & & & & & & & & o & & & \\
\hline Minuartia mediterranea & $\mathrm{HO}$ & $\mathrm{i}$ & & & & & & & & & & & r & r & \\
\hline Moenchia erecta & $\mathrm{HO}$ & $\mathrm{i}$ & & & & & & $r$ & & & & r & & & \\
\hline Petrorhagia velutina & $\mathrm{HO}$ & $\mathrm{i}$ & & & & & & & & & & & r & $\mathrm{r}$ & \\
\hline Polycarpon tetraphyllum & & $\mathrm{i}$ & & & & & & & & & & o & o & & \\
\hline Sagina apetala & $\mathrm{HO}$ & $\mathrm{i}$ & & & & & o & o & & & & c & & o & \\
\hline S. maritima & $\mathrm{HO}$ & $\mathrm{i}$ & & & & & & & & & & c & & o & \\
\hline Stellaria media & $\mathrm{HO}$ & $\mathrm{i}$ & & & & & & & & & & & & o & \\
\hline S. multiflora & $\mathrm{HO}$ & & & & & & & & & & & o & & & \\
\hline S. pungens & $\mathrm{HO}$ & & $\mathrm{r}$ & & & & & & & & & & & & \\
\hline \multicolumn{16}{|l|}{ CHENOPODIACEAE } \\
\hline Atriplex cinerea & $\mathrm{HO}$ & & & & & & & & & & & o & & & \\
\hline Chenopodium glaucum & $* 1$ & & & & & & & & & & & o & & & \\
\hline Sarcocornia quinqueflora & $\mathrm{HO}$ & & & & & & & & & & & o & & & \\
\hline
\end{tabular}


Appendix cont.

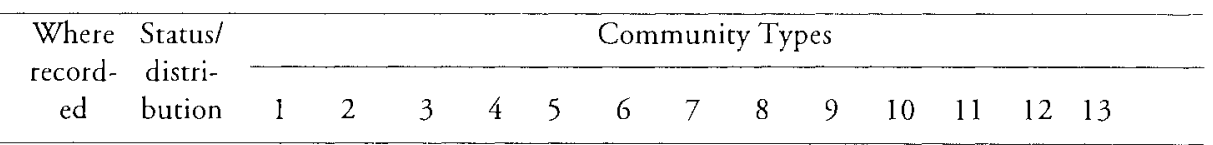

Rhagodia candolleana subsp. candolleana

\section{Clustaceae}

Hypericum japonicum

Convolvulaceae

Dichondra repens

Crassulaceae

Crassula decumbens

C. helmsii

C. sieberana subsp. sieberana

C. sieberana subsp. tetramera

Cunonlaceae

Bauera rubioides

Dilleniaceae

Hibbertia procumbens

H. prostrata

Droseraceae

Drosera peltata

D. pygmaea

EPACRIDACEAE

Acrotriche serrulata

Cyathodes juniperina

Epacris impressa

E. lanuginosa

E. obtusifolia

Leucopogon australis

L. collinus

L. ericoides

L. parviflorus

Monotoca glauca

Sprengelia incarnata

Euphorbiaceae

Amperea xiphoclada

Euphorbia paralias

E. peplus

Phyllanthus gunnii

FABACEAE

Aotus ericoides

Dillwynia glaberrima

Kennedia prostrata

Pultenaea daphnoides var. obcordatum

$P$. dentata

Trifolium cernuum

T. subterraneum

Vicia sativa

Gentianaceae

Centaurium erythraea

Gerantaceae

Erodium cicutarium

Geranium potentilloides

Pelargonium australe

Goodeniaceae

Selliera radicans

Haloragaceae

Haloragis brownii

Myriophyllum salsugineum

Gonocarpus micranthus subsp. micranthus

$\mathrm{HO}$

$\mathrm{HO}$

$\mathrm{HO}$

$\mathrm{HO}$

$\mathrm{HO}$

$\mathrm{HO}$

HO

HO

$\mathrm{HO}$

$\mathrm{HO}$

$\mathrm{HO}$

$\mathrm{HO}$

$\mathrm{HO}$

$\mathrm{HO}$

$\mathrm{HO}$

$\mathrm{HO}$

HO

HO

$\mathrm{HO}$

$\mathrm{HO}$

HO

$\mathrm{HO}$

$\mathrm{HO}$

$\mathrm{HO}$

HO

$\mathrm{HO}$

HO

$\mathrm{HO}$

HO

HO

$\mathrm{HO}$

HO

HO i

HO

$\mathrm{HO}$

$* 1$

$\mathrm{HO}$

o

o

$\begin{array}{llllllll}c & \mathrm{o} & \mathrm{C} & \mathrm{r} & \mathrm{O} & \mathrm{C} & \mathrm{C} & \mathrm{C}\end{array}$

o

$\begin{array}{llllll}o & o & r & c & c & c\end{array}$

o

o 
Appendix cont.

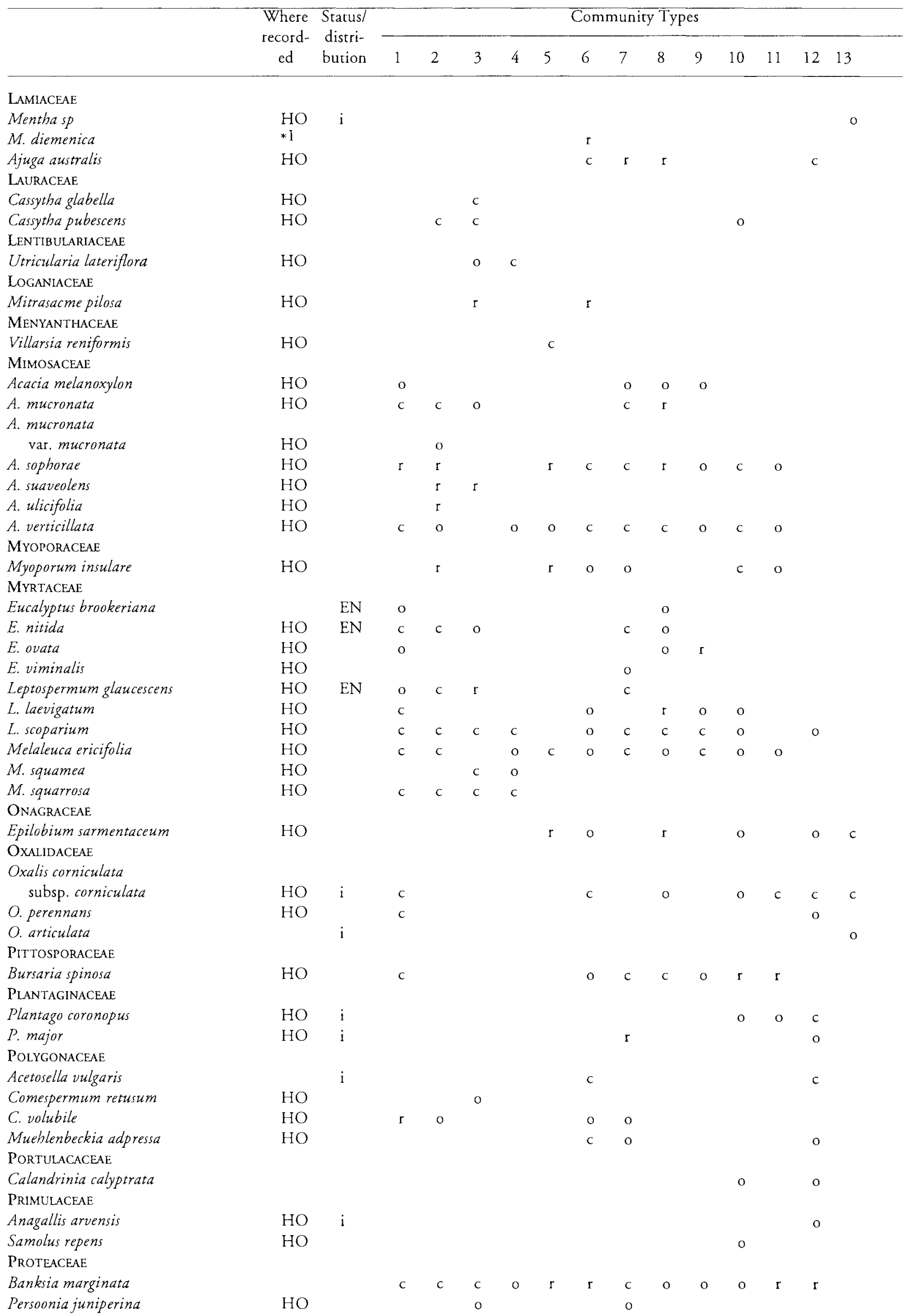


Appendix cont.

\begin{tabular}{|c|c|c|c|c|c|c|c|c|c|c|c|c|c|c|c|}
\hline & \multirow{2}{*}{$\begin{array}{l}\text { Where } \\
\text { record- } \\
\text { ed }\end{array}$} & \multirow{2}{*}{$\begin{array}{l}\text { Status/ } \\
\text { distri- } \\
\text { bution }\end{array}$} & \multicolumn{13}{|c|}{ Community Types } \\
\hline & & & 1 & 2 & 3 & 4 & 5 & 6 & 7 & 8 & 9 & 10 & 11 & 12 & 13 \\
\hline \multicolumn{16}{|l|}{ RANUNCULACEAE } \\
\hline Clematis aristata & $\mathrm{HO}$ & & 0 & & & & & & $r$ & o & r & & & & \\
\hline C. microphylla & $\mathrm{HO}$ & & & & & & & & 0 & & & & & & \\
\hline Ranunculus amphitrichus & $\mathrm{HO}$ & & & & & & c & & & & & & & o & \\
\hline R. parviflorus & $\mathrm{HO}$ & & & & & & & & & & & o & & & \\
\hline R. repens & $\mathrm{HO}$ & $\mathrm{i}$ & & & & & & & & & & & & r & o \\
\hline \multicolumn{16}{|l|}{ RHAMNACEAE } \\
\hline Pomaderris apetala & $\mathrm{HO}$ & & o & & & & & & & & & & & & \\
\hline \multicolumn{16}{|l|}{ ROSACEAE } \\
\hline Acaena novae-zelandiae & $\mathrm{HO}$ & & & $\mathrm{r}$ & & & $r$ & c & $r$ & o & & c & c & c & \\
\hline A. pallida & $\mathrm{HO}$ & & & & & & & o & & & & o & o & & \\
\hline \multicolumn{16}{|l|}{ RUBIACEAE } \\
\hline Coprosma quadrifida & & & & & & & & & & r & & & & & \\
\hline C. repens & & $\mathrm{i}$ & & & & & & o & $r$ & & & 0 & & & c \\
\hline Galium australe & $\mathrm{HO}$ & & & & & & & & o & & o & o & & & \\
\hline \multicolumn{16}{|l|}{ RUTACEAE } \\
\hline Boronia anemonifolia & $\mathrm{HO}$ & & c & c & o & & & & c & o & o & & o & & \\
\hline B. parviflora & $\mathrm{HO}$ & & & & $r$ & & & & & & & & & & \\
\hline Correa backhousiana & $\mathrm{HO}$ & & & & & & & & & & o & c & o & & \\
\hline Zieria arborescens & $\mathrm{HO}$ & & & & & & & & & & o & & & & \\
\hline \multicolumn{16}{|l|}{ SALICACEAE } \\
\hline Salix sp. & $\mathrm{HO}$ & $\mathrm{i}$ & & & & & & & & & & & & & o \\
\hline \multicolumn{16}{|l|}{ SCROPHULARIACEAE } \\
\hline Gratiola peruviana & $\mathrm{HO}$ & & & & & & & & & & & r & & & \\
\hline Limosella australis & $\mathrm{HO}$ & & & & & & $\mathrm{c}$ & & & & & $r$ & & & \\
\hline Parentucellia latifolia & $\mathrm{HO}$ & $\mathrm{i}$ & & & & & & o & & & & & & & \\
\hline \multicolumn{16}{|l|}{ SOLANACEAE } \\
\hline Lycium ferocissimum & & $\mathrm{i}$ & & & & & & & & & & & & & c \\
\hline Solanum vescum & $\mathrm{HO}$ & & & & & & $r$ & & & & r & & o & & \\
\hline \multicolumn{16}{|l|}{ STACKHOUSIACEAE } \\
\hline Stackhousia spathulata & $\mathrm{HO}$ & & & & & & & & & & & o & & & \\
\hline \multicolumn{16}{|l|}{ THYMELAEACEAE } \\
\hline Pimelea drupacea & $\mathrm{HO}$ & & $r$ & & & & & & & & & & & & \\
\hline$P$. linifolia & $\mathrm{HO}$ & & $\mathrm{c}$ & c & & & & 0 & c & c & o & & & & \\
\hline \multicolumn{16}{|l|}{ URTICACEAE } \\
\hline Parietaria debilis & $\mathrm{HO}$ & & & & & & & & & & & o & o & & \\
\hline Urtica incisa & $\mathrm{HO}$ & & $r$ & & & & o & o & o & & & o & c & o & \\
\hline \multicolumn{16}{|l|}{ Violaceae } \\
\hline Viola bederacea & $\mathrm{HO}$ & & & o & & & & c & $r$ & o & & & & c & \\
\hline
\end{tabular}

\section{MONOCOTYLEDONAE}

AgavaCEAE

Phormium tenax

ARACEAE

Zantedeschia aethiopica

CentrolepidaceaE

Centrolepis fascicularis

C. polygyna

C. strigosa

Cyperaceae

Baumea acuta

B. arthrophylla

B. junced

Carex appressa

C. breviculmis

Eleocharis acuta

E. pusilla

Gahnia grandis

G. trifida

Isolepis fluitans 
Appendix cont.

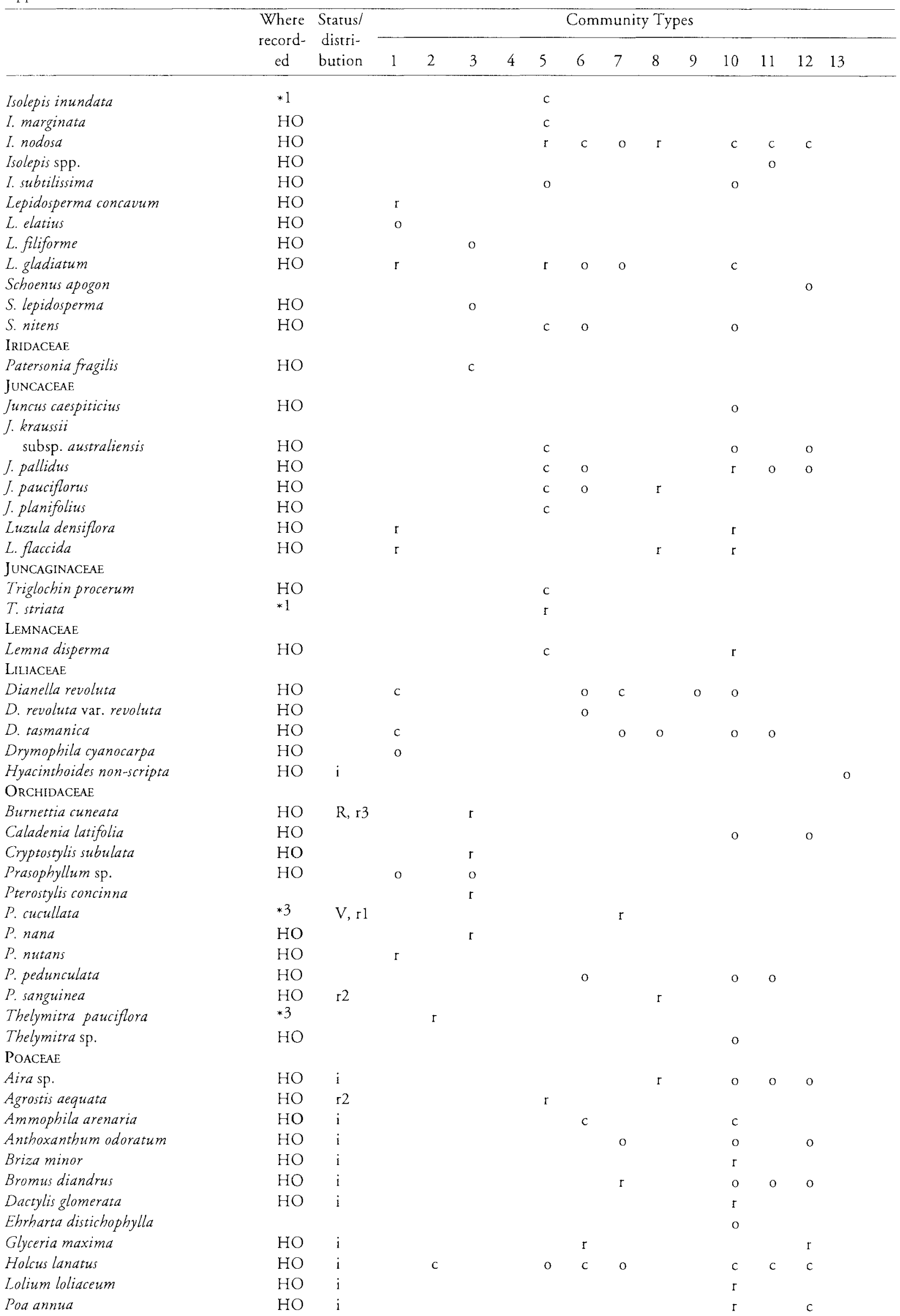


Appendix cont.

\begin{tabular}{|c|c|c|c|c|c|c|c|c|c|c|c|c|c|c|c|}
\hline & \multirow{2}{*}{$\begin{array}{l}\text { Where } \\
\text { record- } \\
\text { ed }\end{array}$} & \multirow{2}{*}{$\begin{array}{l}\text { Status/ } \\
\text { distri- } \\
\text { bution }\end{array}$} & \multicolumn{13}{|c|}{ Community Types } \\
\hline & & & 1 & 2 & 3 & 4 & 5 & 6 & 7 & 8 & 9 & 10 & 11 & 12 & 13 \\
\hline Poa labillardierei & $\mathrm{HO}$ & & o & & & & & $c$ & & o & & & & & \\
\hline P. poiformis & $\mathrm{HO}$ & & o & o & & & & c & c & o & $\mathrm{c}$ & c & c & c & \\
\hline P. poiformis var ramifer & $\mathrm{HO}$ & & & & & & & & & & & o & o & & \\
\hline Spinifex sericeus & & & & & & & & & & & & o & & & \\
\hline Stipa stipoides & & & & & & & & & & & & c & & & \\
\hline Vulpia bromoides & $\mathrm{HO}$ & $\mathrm{i}$ & & & & & & & $r$ & & & & & o & \\
\hline \multicolumn{16}{|l|}{ RESTIONACEAE } \\
\hline Empodisma minus & $\mathrm{HO}$ & & & & c & c & & & & & & & & & \\
\hline Lepyrodia tasmanica & $\mathrm{HO}$ & & & & c & c & & & & & & & & & \\
\hline Restio complanatus & $\mathrm{HO}$ & & & & c & & & & & & & & & & \\
\hline R. tetraphyllus & $\mathrm{HO}$ & & & & 0 & c & & & & & & & & & \\
\hline \multicolumn{16}{|l|}{ RUPPIACEAE } \\
\hline Ruppia polycarpa & $* 1$ & & & & & & & & & & & $r$ & & & \\
\hline \multicolumn{16}{|l|}{ XYRIDACEAE } \\
\hline Xyris muelleri & $\mathrm{HO}$ & & & & o & & & & & & & & & & \\
\hline \multicolumn{16}{|l|}{ GYMNOSPERMAE } \\
\hline \multicolumn{16}{|l|}{ ARAUCARIACEAE } \\
\hline Araucaria heterophylla & $\mathrm{HO}$ & $\mathrm{i}$ & & & & & & & & & & & & & $\mathrm{r}$ \\
\hline \multicolumn{16}{|l|}{ CUPPRESSACEAE } \\
\hline Cupressus macrocarpus & $\mathrm{HO}$ & $\mathrm{i}$ & & & & & & & & & & & & & o \\
\hline \multicolumn{16}{|l|}{ PINACEAE } \\
\hline Pinus radiata & & $\mathrm{i}$ & & & & & & & & & & & & & 0 \\
\hline \multicolumn{16}{|l|}{ PTERIDOPHYTA } \\
\hline \multicolumn{16}{|l|}{ ASPLENIACEAE } \\
\hline Asplenium obtusatum & $\mathrm{HO}$ & & & & & & & & & & & c & & & \\
\hline \multicolumn{16}{|l|}{ AZOLLACEAE } \\
\hline Azolla filiculoides & $\mathrm{HO}$ & & & & & & o & & & & & & & & \\
\hline \multicolumn{16}{|l|}{ BLECHNACEAE } \\
\hline Blechnum wattsii & $\mathrm{HO}$ & & o & & & & & & & & & & & & \\
\hline \multicolumn{16}{|l|}{ DENNSTAEDTLACEAE } \\
\hline Histiopteris incisa & $\mathrm{HO}$ & & o & & & & & & & 0 & c & & & & \\
\hline Pteridium esculentum & $\mathrm{HO}$ & & c & c & & & & $\mathrm{c}$ & $c$ & c & c & o & $c$ & $c$ & \\
\hline Hypolepis rugosula & $\mathrm{HO}$ & & o & & & & & & & o & & & & & \\
\hline Hypolepis sp. & $\mathrm{HO}$ & & r & & & & & & & & & & & & \\
\hline DICKSONIACEAE & & & & & & & & & & & & & & & \\
\hline Dicksonia antarctica & $\mathrm{HO}$ & & r & & & & & & & r & & & & & \\
\hline DRYOPTERIDACEAE & & & & & & & & & & & & & & & \\
\hline Rumohra adiantiformis & $\mathrm{HO}$ & & & & & & & & & & & t & & & \\
\hline GLEICHENIACEAE & & & & & & & & & & & & & & & \\
\hline Gleichenia microphylla & $\mathrm{HO}$ & & o & r & & $c$ & & & & & & & & & \\
\hline GRAMMITIDACEAE & & & & & & & & & & & & & & & \\
\hline Grammitis sp. & $\mathrm{HO}$ & & r & & & & & & & & & & & & \\
\hline Polypodiaceae & & & & & & & & & & & & & & & \\
\hline Phymatosorus pustulatus & $\mathrm{HO}$ & & $r$ & & & & & & $r$ & r & & r & & & \\
\hline PTERIDACEAE & & & & & & & & & & & & & & & \\
\hline Pteris tremula & $\mathrm{HO}$ & & $r$ & & & & & & & & & & & & \\
\hline SCHIZAEACEAE & & & & & & & & & & & & & & & \\
\hline Schizaea fistulosa & $\mathrm{HO}$ & & & & o & c & & & & & & & & & \\
\hline SELAGinellaCeAE & & & & & & & & & & & & & & & \\
\hline Selaginella uliginosa & $\mathrm{HO}$ & & & & $\mathrm{c}$ & & & & & & & & & & \\
\hline
\end{tabular}

